UNIVERSIDADE DE SÃO PAULO

FACULDADE DE ECONOMIA, ADMINISTRAÇÃO E CONTABILIDADE

DEPARTAMENTO DE ECONOMIA

PROGRAMA DE PÓS-GRADUAÇÃO EM ECONOMIA

\title{
A ECONOMIA POLÍTICA DOS ACORDOS PREFERENCIAIS DE COMÉRCIO - APLICAÇÃO DE UM JOGO NÃO-COOPERATIVO DE STACKELBERG NA ANÁLISE DA ÁREA DE LIVRE-COMÉRCIO DAS AMÉRICAS -
}

Orientadora: Profa. Dra. Fabiana Fontes Rocha 
Prof. Dr. Adolpho José Melfi

Reitor da Universidade de São Paulo

Profa. Dra. Maria Tereza Leme Fleury

Diretora da Faculdade de Economia, Administração e Contabilidade

Prof. Dr. Ricardo Abramovay

Chefe do Departamento de Economia

Profa. Dra. Fabiana Fontes Rocha

Coordenadora do Programa de Pós-Graduação em Economia 
DANIEL AUGUSTO MOTTA

\section{A ECONOMIA POLÍTICA DOS ACORDOS PREFERENCIAIS DE COMÉRCIO - APLICAÇÃO DE UM JOGO NÃO-COOPERATIVO DE STACKELBERG NA ANÁLISE DA ÁREA DE LIVRE-COMÉRCIO DAS AMÉRICAS -}

Tese apresentada ao Departamento de Economia da Faculdade de Economia, Administração e Contabilidade da Universidade de São Paulo como requisito para a obtenção do título de Doutor em Economia

Orientadora: Profa. Dra. Fabiana Fontes Rocha

SÃO PAULO 


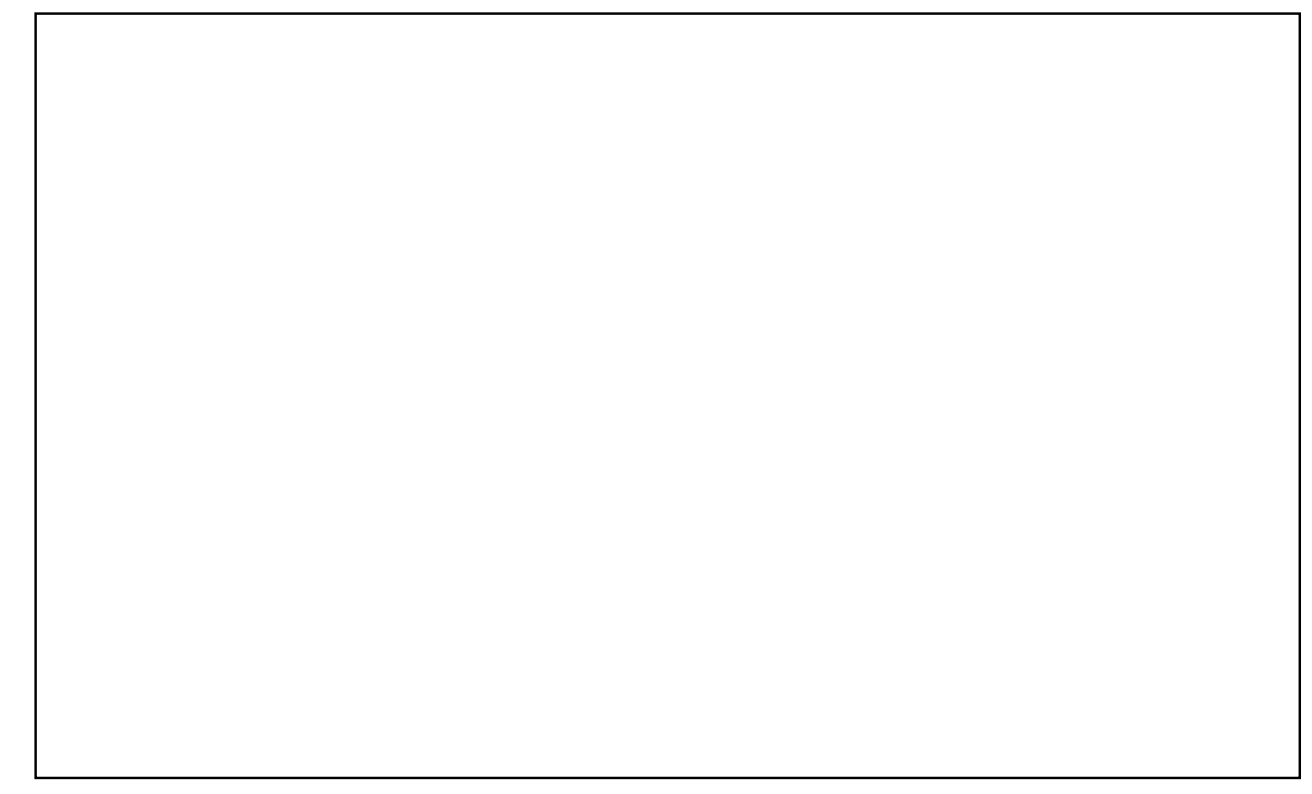

Motta, Daniel Augusto

A economia política dos acordos preferenciais de comércio : aplicação de um jogo não-cooperativo de Stackelberg na análise da Área de Livre Comércio das Américas / Daniel Augusto Motta. -- São Paulo, 2005.

$70 \mathrm{p}$.

Tese (Doutorado) - Universidade de São Paulo, 2005

Bibliografia

1. Economia política 2 Área de Livre Comércio das Américas 3. Teoria dos jogos I. Universidade de São Paulo. Faculdade de Economia, Administração e Contabilidade. II. Título.

CDD -330.1 
À Ana Paula, cujo coração decidido torna impossivvel o impossível. 
Agradeço à minha professora Fabiana Fontes Rocha por ter compartilhado este sonho comigo. 
“A política não é o jogo da intriga, da inveja e da incapacidade, a que entre nós se deu a alcunha de politicagem."

Rui Barbosa 
RESUMO

O objetivo desta tese é analisar a economia política dos acordos preferenciais de comércio (APC) a partir de um jogo político seqüencial não-cooperativo de Stackelberg entre uma grande economia e uma pequena economia, onde a disputa política entre grupos lobistas rivais define as preferências unilaterais dos governos no primeiro estágio e o equilíbrio coalitionproof de Stackelberg define o formato do acordo de livre comércio no segundo estágio. Então se modifica a estrutura inicial do jogo político bilateral para um processo de barganha entre $\mathrm{n}$ países. Finalmente, aplica-se o modelo teórico ao caso particular da ALCA. 


\begin{abstract}
The purpose of this paper is to analyse the political economy of preferential trade agreements (PTA) based on a sequential non-cooperative Stackelberg political game between a large economy and a small economy, in which the political dispute of rival lobby groups defines the unilateral stance of both governments in the first stage and the Stackelberg coalition-proof equilibrium defines the format of the free trade agreement in the second stage. Then the initial bilateral political game hypothesis is relaxed to accomplish a more complex bargaining game with $\mathrm{n}$ economies. Finally the theoretical framework is applied to FTAA.
\end{abstract}




\section{SUMÁRIO}

1 - Introduçã

2 -Breve Revisão da Literatura.............................................................................................. 4

2.1 Teoria de Jogos de Barganha e Não-cooperativos ..........................................................................................

2.2 Economia Política dos Acordos Preferenciais de Comércio .............................................................................. 6

3 -O Primeiro Estágio do Jogo Político Bilateral ............................................................... 2

3.1 Estratégias e bem-estar no modelo de Grossman e Helpman ................................................................... 3

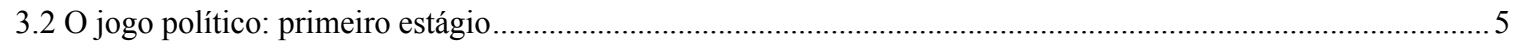

4 - O Segundo Estágio do Jogo Político Bilateral.................................................................. 12

4.1 O equilíbrio “coalition-proof” no jogo político bilateral de Stackelberg ....................................................... 13

4.2 O pode de negociação da pequena economia seguidora de Stackelberg .................................................. 14

5 - A Economia Política da ALCA: O Jogo Político com N Países.......................................... 22

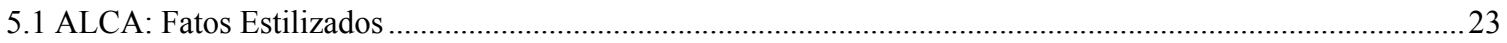

5.2 O jogo de barganha de Nash com n jogadores: variações do modelo Grossman e Helpman ..........................26

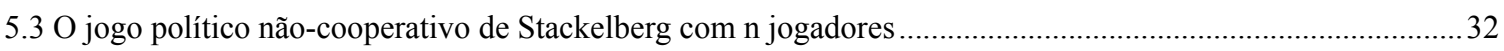

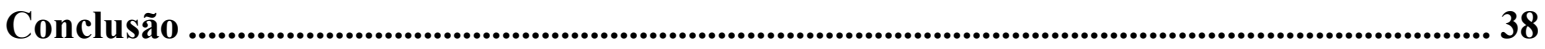

Referências Bibliográficas ...................................................................................................................... 40

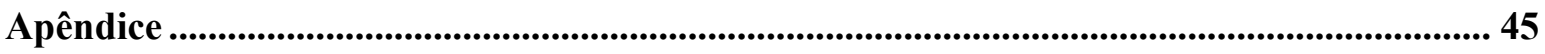

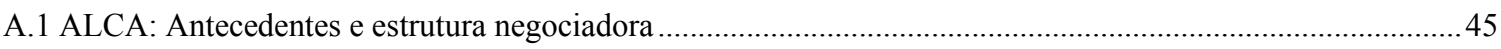

A.2 Modelo Grossman e Helpman (1995): definições e proposições ................................................................49

A.3 Jogo político bilateral não-cooperativo de Stackelberg: proposições e provas ...............................................52

A.4 Jogo político com n países: proposiç̧̃es e provas.................................................................................56 


\section{INTRODUÇÃO}

Quais fatores políticos determinam a viabilidade política e o formato desses acordos preferenciais de comércio? Como os governos envolvidos nessas negociações são influenciados pela ação política coordenada de lobbies? Por que alguns setores econômicos mantêm-se protegidos por barreiras protecionistas mesmo com o início do prazo de vigência de acordos preferenciais de comércio?

Tradicionalmente ignoradas pela abordagem clássica de bem-estar social baseada em Viner (1950) sobre os efeitos de criação e desvio de comércio inerentes às alterações dos termos de troca provocadas por um acordo preferencial de comércio, essas questões são respondidas pela teoria de economia política dos acordos preferenciais de comércio. Neste caso, o formato e a viabilidade dos acordos de comércio estão relacionados à capacidade de atuação política coordenada de lobbies em influenciar as posições estratégicas dos seus respectivos representantes governamentais em negociações internacionais. ${ }^{1}$

Neste contexto, diante do aprofundamento da liberalização multilateral do comércio e das negociações bilaterais ou regionais para a formação de acordos preferenciais de comércio (como, por exemplo, União Européia, NAFTA e Mercosul) ${ }^{2}$, esta tese de doutorado concentra-se na análise dos incentivos políticos e econômicos à implementação e sustentação de um acordo preferencial de comércio entre economias assimétricas, aplicando-se os resultados do modelo teórico ao atual processo de negociação para criação da Área de Livre Comércio das Américas (ALCA).

Inicialmente, com base em algumas modificações na estrutura do modelo de economia política de Grossman e Helpman (1995), analisa-se a economia política de um acordo preferencial de comércio (APC) com base na polarização das negociações entre uma pequena economia e uma grande economia em um jogo político bilateral não-cooperativo realizado em dois estágios.

\footnotetext{
${ }^{1}$ Viner (1950), Lipsey (1957), Bhagwati (1971), Kemp e Wan (1976), Dixit e Norman (1980) e Krugman (1991) apresentam as principais contribuições teóricas envolvendo criação e desvio de comércio versus bem-estar na formação de uniões aduaneiras. Ver Bhagwati e Panagariya (1996) para uma ampla revisão bibliográfica.

${ }^{2}$ Ver Obstfeld (1998), Krueger (1999) e Lucinda (1999), respectivamente.
} 
No primeiro estágio definem-se as preferências unilaterais dos governos das duas economias envolvidas no processo de barganha política para implementação do APC. No segundo, os governos participam do processo de negociação internacional para definição do formato do APC. Ambos os governos definem o conjunto de setores econômicos que serão incluídos no APC, com a eliminação de suas barreiras protecionistas, e o conjunto de setores excluídos do APC, com a preservação (eventualmente elevação) de seu protecionismo. Neste processo, os governos têm suas preferências unilaterais influenciadas pela atuação política coordenada por grupos lobistas e pelo seu interesse no bem-estar do agente eleito médio.

Nesta tese, a aplicação de um jogo político bilateral entre uma pequena economia (eventualmente, o Brasil) e uma grande economia (eventualmente, os Estados Unidos) no formato não-cooperativo de Stackelberg justifica-se pela assimetria de poder entre as duas economias, em que a liderança está relacionada tanto à assimetria per se entre a grande economia e a pequena economia em termos de PIB, como à participação significativa da grande economia nos fluxos comerciais da pequena economia.

Além disso, analisam-se duas alterações do poder de negociação da pequena economia no segundo estágio do jogo político não-cooperativo de Stackelberg. De um lado, a formação de uma aliança estratégica com outras pequenas economias na negociação com a grande economia. De outro lado, a possibilidade de a pequena economia também negociar com uma terceira economia.

Então, com o objetivo de adequar a estrutura teórica do modelo para a análise da economia política da ALCA, a estrutura bilateral do jogo político é ampliada para um processo de barganha política envolvendo n países negociando o formato de um APC.

Além desta introdução, a tese está assim organizada: o capítulo 2 apresenta uma breve revisão da literatura de teoria dos jogos e da teoria de acordos preferenciais de comércio. O capítulo 3 replica os pressupostos e o primeiro estágio do modelo de Grossman e Helpman (1995). O capítulo 4 apresenta o segundo estágio do modelo na estrutura não-cooperativa de Stackelberg, discutindo alterações no poder de negociação da pequena economia. O capítulo 5 apresenta o jogo político não-cooperativo com n países. A conclusão resume os principais resultados desta tese. 


\section{BREVE REVISÃO DA LITERATURA}

\subsection{Teoria de jogos de barganha e não-cooperativos ${ }^{3}$}

A partir do trabalho pioneiro de Nash (1950, 1953), Rubinstein (1982) e Binmore et al. (1986) desenvolvem uma abordagem dinâmica para o processo contínuo de barganha entre os agentes econômicos, enquanto Harsanyi (1967) e Harsanyi e Selten (1972) analisam o processo de barganha sob informação incompleta, em que os participantes estabelecem distribuição de probabilidades subjetiva sobre as estratégias dos seus oponentes.

Grossman e Perry (1986) analisam o adiamento no timing para a conclusão de um jogo de barganha na presença de informação incompleta entre vendedores e compradores em um mercado oligopolista, no qual um comprador pode decidir rejeitar a oferta do vendedor e também fazer uma contra-oferta recusável ao vendedor. Neste contexto, mesmo na presença de uma taxa de desconto sobre os ganhos de vendedores e compradores, o processo de barganha pode se prolongar ao longo de diversas rodadas. Nesta tese, analisam-se os impactos dos custos de adiamento sobre a decisão da pequena economia entre continuar negociando com a grande economia ou optar pelo início das negociações com outra economia (oportunidade externa). Admati e Perry (1987) apontam o adiamento à conclusão do jogo como uma sinalização de força entre os participantes em um processo de barganha com informação incompleta, ou seja, o tempo entre ofertas e contra-ofertas torna-se também uma variável estratégica no processo de barganha, e não uma variável exógena constante. Neste sentido, Dekel (1990) salienta a perda de eficiência decorrente do adiamento da conclusão do jogo de barganha entre jogadores muito pacientes, onde cada jogador já inicia o jogo com expectativas definidas, não sendo influenciado pelas contra-ofertas dos oponentes.

Fudenberg e Tirole (1983) caracterizam o processo de adiamento nas negociações como um processo oneroso de sinalização entre os oponentes. Alternativamente, Farrell e Gibbons (1989) desenvolvem um modelo de barganha com sinalização sem custos, em que os participantes conversam sobre suas prováveis jogadas no primeiro estágio e efetivamente negociam no segundo reduzindo a probabilidade de adiamento no processo de barganha. 
Naturalmente, um processo de barganha pode envolver inúmeros participantes, em vez do tradicional modelo comprador versus vendedor ou, do mesmo modo, firma entrante versus firma estabelecida. Rosenthal (1979) analisa o comportamento de participantes envolvidos em uma seqüência de jogos de barganha - não necessariamente os mesmos jogos, os mesmos oponentes, o mesmo conjunto de informações —, onde cada participante apresenta distribuições subjetivas de probabilidade descrevendo o comportamento de seu oponente em um jogo específico e o tipo de oponente a ser enfrentado no próximo jogo. Neste modelo, o equilíbrio é definido como uma seqüência de equilíbrios de Nash em cada uma das rodadas de negociação. Fudenberg e Levine (1989) analisam um jogo simultâneo não-cooperativo entre um único jogador de longo prazo e inúmeros oponentes de curto prazo, onde o primeiro adota a estratégia de líder de Stackelberg, restando a todos os seus oponentes atuar como seguidores de Stackelberg. Aplicam-se nesta tese alguns dos resultados deste modelo para o jogo político não-cooperativo com n países negociando a formação de um APC.

Mailath e Postlewaite (1990) analisam um processo de barganha com diversos participantes sob informação incompleta a respeito da escolha dos oponentes, onde cada participante tem poder de veto e, portanto, a decisão final deve refletir um consenso entre todos os participantes, cuja probabilidade converge para zero com o aumento do número de participantes. Esta tese de doutorado aplica este resultado no jogo político com n países negociando a criação de um APC, principalmente no formato da ALCA, de modo que cada decisão deve refletir o consenso entre todos os 34 países com características econômicas e expectativas comerciais significativamente distintas.

\footnotetext{
${ }^{3}$ Ver Tirole (2000) e Fudenberg e Tirole (2000) para ampla revisão bibliográfica. Além disso, ver Friedman (1970), Fudenberg e Levine (1983) e Fudenberg, Kreps e Levine (1988) para os principais refinamentos da teoria de jogos de barganha cooperativos e não-cooperativos.
} 


\subsection{Economia política dos acordos preferenciais de comércio}

Não obstante sua aplicação generalizada à Nova Organização Industrial e à teoria da Escolha Pública, os modelos de teoria dos jogos têm sido amplamente utilizados no âmbito da teoria de Comércio Internacional. Basicamente, analisa-se a economia política da estrutura comercial protecionista, dos acordos preferenciais de comércio e das relações internacionais de comércio, a partir da interação entre grupos de interesse politicamente organizados e os respectivos governos nacionais interessados tanto nas contribuições financeiras decorrentes do alinhamento da política de comércio exterior às demandas dos grupos de interesse como no bem-estar de um agente-eleitor médio. ${ }^{4}$

Mais especificamente, do mesmo modo que a estrutura comercial protecionista de equilíbrio definida por um governo estaria diretamente vinculada à maximização de uma soma ponderada entre o bem-estar social de um agente-eleitor médio e o total de contribuições lobistas, também a formação de acordos preferenciais de comércio estaria sujeita a fortes pressões lobistas por parte de grupos de interesse politicamente organizados sobre os governos dos respectivos países. ${ }^{5}$

Naturalmente, conforme apontam Krueger (1974) e Grossman e Helpman (1994), nesse processo de barganha política pelo protecionismo, grupos de interesse politicamente organizados vinculariam suas contribuições financeiras à política comercial definida pelo governo na expectativa de influenciar a estrutura de barreiras comerciais de equilíbrio, investindo recursos financeiros em campanhas lobistas até que o retorno marginal da última unidade monetária investida fosse igual ao ganho decorrente da política comercial protecionista adotada pelo governo, maximizando a utilidade dos membros dos respectivos

\footnotetext{
${ }^{4}$ Mayer (1984) e Baldwin (1976) analisam as decisões políticas referentes à estrutura tarifária a partir da interação entre interesses de grupos lobistas, agente-eleitor e políticos. Bhagwati (1980) e Bhagwati e Srinivasan (1980) analisam a importância de grupos lobistas rent-seeking. Brock e Magee (1978) analisam o processo de definição da estrutura tarifária a partir de um jogo não-cooperativo entre grupos lobistas rivais. Richardson (1993) analisa os efeitos criação de comércio e desvio de comércio decorrentes de um acordo preferencial de comércio, quando a estrutura tarifária é definida endogenamente através da interação entre grupos lobistas e políticos. Hillman e Ursprung (1988) analisam os impactos de contribuições lobistas de grupos estrangeiros sobre o formato do acordo preferencial de comércio. Ver também Helpman e Krugman (1991a, 1991b).

${ }^{5} \mathrm{O}$ termo lobby não deve ser utilizado como sinônimo de corrupção política (bribery), mas como contribuições financeiras feitas por grupos empresariais ao governo de maneira transparente na forma de financiamento de projetos públicos, financiamento de campanha política ou, simplesmente, doações financeiras feitas ao governo. Desconsidera-se nesta tese de doutorado a possibilidade de os grupos empresariais corromperem autoridades governamentais em troca de favorecimento nas políticas públicas.
} 
grupos lobistas. Neste contexto, cada grupo lobista assume como exógenas as contribuições financeiras dos demais grupos lobistas na definição de sua estratégia junto ao governo.

Grossman e Helpman (1994) e Helpman (1995) analisam o processo de barganha política inerente à definição da estrutura protecionista de equilíbrio a partir da estrutura teórica agenteprincipal desenvolvida por Bernheim e Whinston (1986), segundo a qual grupos de interesse oferecem um conjunto de políticas factíveis e potencialmente custosas ao governo vinculando suas contribuições financeiras às políticas realmente implementadas. ${ }^{6}$

Ainda segundo Grossman e Helpman (1994), o pressuposto fundamental dos modelos de economia política está no tratamento do governo como um agente maximizador de seus próprios interesses em vez de uma entidade benevolente maximizadora exclusiva do bemestar social e dos interesses nacionais, conforme modelagem tradicional sugerida por Viner (1950) e Samuelson (1962) para análise dos efeitos criação e desvio de comércio sobre o bemestar social de uma economia.

Nesse sentido, o governo "vende" a estrutura de barreiras protecionistas àqueles grupos de interesse com contribuições financeiras mais elevadas, enquanto a atribuição de certa importância ao bem-estar do agente-eleitor médio reflete simplesmente a preocupação do governo com os resultados políticos das próximas eleições.

Krishna (1998) define a política comercial nacional como um bem público, cujos benefícios são "capturados" por grupos de interesse politicamente organizados em detrimento dos interesses difusos e desorganizados do restante da população, resultando um apoio político maior nos países-membros para acordos preferenciais de comércio com efeito desvio de comércio predominante. Conseqüentemente, como observado por Krueger (1995), como resultado da atuação dos grupos lobistas, o formato do acordo preferencial de comércio politicamente viável difere do acordo socialmente desejável.

Finalmente, Grossman e Helpman (1995) analisam os incentivos políticos e econômicos à formação de um acordo preferencial de comércio entre duas pequenas economias a partir de um jogo estratégico seqüencial, onde a disputa política entre os grupos de interesse determina

\footnotetext{
${ }^{6}$ Ver também Bernheim, Peleg e Whinston (1987) e Bernheim e Whinston (1987).
} 
as preferências políticas dos governos nas duas economias em um primeiro estágio e o processo de barganha internacional entre os governos determina a viabilidade e o formato do acordo preferencial de comércio no estágio subseqüente.

Trata-se do referencial teórico básico ao jogo político seqüencial não-cooperativo entre duas economias assimétricas desenvolvido neste trabalho.

Mais especificamente, pretende-se substituir um jogo seqüencial de barganha política entre duas pequenas economias por um jogo político seqüencial não-cooperativo em dois estágios entre uma pequena economia e uma grande economia, no qual a última assume o papel de líder de Stackelberg na definição do formato do acordo preferencial de comércio.

No primeiro estágio do jogo não há negociação entre as economias, sendo que cada governo define suas preferências unilaterais quanto ao formato do acordo com base em uma maximização ponderada entre o bem-estar de seus agentes-eleitores e as contribuições financeiras dos grupos lobistas politicamente organizados. Neste estágio, os grupos lobistas interagem de forma não-cooperativa definindo suas respectivas contribuições financeiras na tentativa de influenciar a decisão final do governo sobre o formato do acordo preferencial de comércio.

Então, uma vez definidas as preferências unilaterais dos governos, inicia-se o processo de negociação entre as economias sobre o formato do acordo preferencial de comércio no segundo estágio do jogo. Neste último estágio, a assimetria econômica entre as economias reflete-se na distribuição dos ganhos decorrentes do acordo preferencial de comércio, sendo que a grande economia (líder de Stackelberg) maximiza seus ganhos em detrimento da pequena economia (seguidora de Stackelberg), onde os ganhos obtidos pelas economias com o acordo decorrem diretamente do conjunto de setores excluídos do processo de liberalização das barreiras protecionistas. Vale salientar que o formato politicamente viável do APC pode eventualmente minimizar ganhos decorrentes do efeito de criação de comércio, ao manter as barreiras protecionistas para os setores econômicos mais sensíveis mesmo após vigência do acordo, ficando ainda suscetível às perdas decorrentes do efeito desvio de comércio. ${ }^{7}$

\footnotetext{
${ }^{7}$ Neste contexto, HIllman (1982) argumenta que os governos tendem a adotar maior protecionismo a setores econômicos em decadência, estando esses últimos mais propensos a elevar suas contribuições financeiras.
} 
Na verdade, segundo Krishna (1998), o aumento do apoio político à formação de um APC está diretamente relacionado à magnitude do efeito desvio de comércio decorrente deste APC em prol dos interesses nacionais dos setores econômicos em ambos os países-membros do APC. Neste caso, o efeito criação de comércio é caracterizado como um jogo de soma zero, com simples trocas dos fluxos comerciais entre os dois países, restando a ambos buscarem maximizar seus benefícios relacionados ao desvio de comércio, inclusive se opondo à liberalização multilateral de tarifas no âmbito das negociações lideradas pela OMC.

Em seguida, propõem-se duas modificações na estrutura básica do jogo não-cooperativo com o objetivo de ampliar o poder de negociação da pequena economia na definição do formato do acordo preferencial de comércio. Em primeiro lugar, como sugerido em Fudenberg e Levine (1989) e Fudenberg, Levine e Tirole (1987), introduz-se a possibilidade de um acordo preferencial de comércio com uma terceira economia como uma oportunidade externa à pequena economia. Em segundo lugar, com base em Rosenthal (1979) e Schiff (1996), analisa-se a participação da pequena economia em uma coalizão de pequenas economias como uma estratégia de redução da assimetria na negociação com a grande economia.

Naturalmente, o jogo político não-cooperativo entre apenas duas economias não esgota todas as possibilidades em torno das negociações para um acordo tão complexo como a Área de Livre Comércio das Américas entre 34 países. Não obstante, mesmo no caso particular da ALCA, a apresentação de um jogo político bilateral justifica-se pela própria polarização das posições políticas dos países em torno do Brasil e dos Estados Unidos. No caso norteamericano, o fato de representar $80 \%$ do PIB de todo continente americano torna o país um líder de Stackelberg nas negociações. No caso brasileiro, além de ser a segunda maior economia do continente com $6,4 \%$ do PIB da região, a inclusão do país no jogo como a pequena economia justifica-se tanto pela posição de liderança assumida pelo Brasil na América Latina quanto pelo alinhamento de Canadá e México à estratégia comercial norteamericana definida no âmbito do NAFTA.

De qualquer forma, mesmo o jogo político bilateral seqüencial de Stackelberg apresenta algumas conclusões muito interessantes sobre o formato e a viabilidade política de um APC entre duas economias significativamente assimétricas quanto ao seu poder de negociação internacional. Em primeiro lugar, assim como em Grossman e Helpman (1995) e Krishna 
(1998), o modelo apresenta a importância da atuação política coordenada dos setores econômicos para a definição da política comercial do governo, em vez da tradicional abordagem de comércio internacional inicialmente proposta por Viner (1950). Em segundo lugar, o modelo aponta a estratégia vencedora do líder de Stackelberg para maximizar seus ganhos em detrimento da pequena economia, que, no entanto, ainda tem interesse em aderir ao APC. Finalmente, o modelo permite algumas modificações no formato do segundo estágio do jogo com o objetivo de aumentar o poder de barganha da pequena economia.

Em seguida, com base em Fudenberg e Kreps (1987), Fudenberg e Levine (1989) e Mailath e Postlewaite (1990), ampliam-se os resultados do jogo político não-cooperativo de Stackelberg entre apenas duas economias para um processo de negociação entre $n$ economias, visando analisar a viabilidade política da ALCA. Neste caso, o primeiro estágio é idêntico ao proposto em Grossman e Helpman (1995) em todas as n economias, sendo uma grande economia e n-1 pequenas economias com tamanhos, pressões políticas e interesses econômicos distintos. No segundo estágio, a grande economia assume a posição de liderança de Stackelberg em negociações simultâneas com as n-1 pequenas economias, que, por sua vez, também negociam entre si, em um total de $S n$ negociações simultâneas, onde cada uma das n economias têm igual poder de veto sobre o APC, e todas as decisões devem ser consenso entre as n economias. Mais uma vez, a variável de escolha é o conjunto de setores econômicos excluídos e incluídos do APC. ${ }^{8}$

Comparam-se os resultados deste modelo com $\mathrm{n}$ economias aos resultados decorrentes do modelo bilateral, demonstrando-se, com base em Mailath e Postlewaite (1990), a crescente dificuldade em se obter um APC politicamente viável para as $\mathrm{n}$ economias à medida que $\mathrm{n}$ aumenta. Então, também com base em Grossman e Helpman (1995), o modelo permite analisar o papel das contribuições financeiras estrangeiras de grupos lobistas de uma economia para os governos das outras economias. Por último, conforme sugerido em Grossman e Helpman (1995), inclui-se a possibilidade de transferências compensatórias entre os governos ao longo do segundo estágio, como mecanismo de incentivo às economias (leiase governos) potencialmente contrárias ao APC.

\footnotetext{
${ }^{8}$ Onde $S n$ equivale à soma de uma progressão aritmética com razão -1 e $n$ termos, sendo (n-1) o primeiro termo e [n-(n-1)] o último termo da progressão aritmética.
} 


\section{O PRIMEIRO ESTÁGIO DO JOGO POLÍTICO BILATERAL}

A partir do trabalho de Grossman e Helpman (1995), a economia política de um APC será analisada a partir de um jogo político seqüencial não-cooperativo em dois estágios entre uma pequena economia e uma grande economia. No primeiro estágio, as preferências políticas dos governos nas duas economias estão vinculadas à maximização de uma soma ponderada entre o bem-estar social de um agente-eleitor médio e o total de contribuições financeiras entre grupos lobistas rivais. No segundo estágio, o formato do APC é definido a partir de um jogo não-cooperativo entre a grande economia e a pequena economia, onde a pequena economia pode escolher entre o status quo e assinar o acordo, enquanto a grande economia líder de Stackelberg obtém resultados potencialmente mais favoráveis em comparação ao equilíbrio de barganha de Nash. Por último, analisa-se o poder de negociação da pequena economia a partir de algumas alterações na estrutura inicial do jogo político, a saber: existência de oportunidades externas à pequena economia e a formação de uma coalizão entre pequenas economias.

De um lado, a existência de oportunidades externas à pequena economia para a formação de um acordo preferencial de comércio refere-se especificamente à inclusão de uma terceira economia no jogo político original, adaptando-se o modelo de Organização Industrial entre um comprador e dois vendedores em um mercado oligopolista desenvolvido por Fudenberg e Levine (1989) e Fudenberg, Levine e Tirole (1987). Neste novo contexto, em função das características econômicas desta terceira economia e dos custos decorrentes do adiamento das negociações para o inicio do acordo preferencial de comércio, a pequena economia tem seu poder de negociação potencialmente elevado no jogo com a grande economia, enquanto esta última obtém ganhos potencialmente inferiores em comparação aos ganhos obtidos no equilíbrio de Stackelberg.

De outro lado, a partir do trabalho de Rosenthal (1979) e Schiff (1996), analisa-se o impacto da coalizão entre pequenas economias nas negociações com uma grande economia para a formação de um acordo preferencial de comércio sobre o poder de negociação da pequena economia comparativamente ao jogo não-cooperativo de Stackelberg. Nossa hipótese básica a respeito da coalizão entre pequenas economias consiste em argumentar que todas as pequenas economias conseguem conciliar internamente seus interesses políticos para, então, negociar 
com a grande economia como um único bloco, reduzindo a assimetria de poder de negociação. Trata-se de uma hipótese frágil a ser relaxada no jogo político com n países, onde cada pequena economia pode assumir sua própria estratégia de negociação em relação à grande economia, bem como em relação às n-2 pequenas economias.

Vale salientar que Grossman e Helpman (1995) ainda desenvolvem a possibilidade de os grupos lobistas vinculados a setores econômicos de uma economia poderem atuar com contribuições financeiras ao governo da outra economia, bem como a possibilidade de os próprios governos realizarem transferências compensatórias entre si após o desfecho do segundo estágio do jogo. Nesta tese de doutorado exploram-se pioneiramente as duas possibilidades no jogo político não-cooperativo de Stackelberg com n economias assimétricas.

Por ora, ao longo dos próximos dois capítulos, nosso objetivo será replicar o primeiro estágio do jogo político bilateral proposto em Grossman e Helpman (1995), modificar o segundo estágio do jogo para um processo de negociação entre uma grande economia líder de Stackelberg e uma pequena economia e aplicar alguns modelos de Organização Industrial na análise do poder de negociação da pequena economia.

A seguir, conforme modelo político desenvolvido por Grossman e Helpman (1995), apresentam-se os objetivos e as funções de bem-estar dos diferentes agentes econômicos residentes nas duas economias.

\subsection{Estratégias e bem-estar no modelo de Grossman e Helpman}

De forma geral, a grande economia (A) e a pequena economia (B) apresentam características internas similares. Em primeiro lugar, cada economia possui uma população de tamanho unitário, cujas preferências individuais, demandas per capita e excedente do consumidor são descritos, respectivamente, por :

(1) $u(c)=c_{0}+\sum_{i=1}^{n} u_{i}\left(c_{i}\right), u^{\prime}(\cdot)>0, u^{\prime \prime}(\cdot)<0$, onde n é o número de bens e 0 refere-se ao numerário

(2) $D_{i}\left(q_{i}\right), i=1, \ldots, n$ e $y-\sum_{i=1}^{n} D_{i}\left(q_{i}\right), i=0$, onde $q_{i}$ : indice de preços ao consumidor doméstico

(3) $S_{i}\left(q_{i}\right)=u_{i}\left[D_{i}\left(q_{i}\right)\right]-q_{i} \cdot D_{i}\left(q_{i}\right)$ 
Em segundo lugar, a produção de cada mercadoria apresenta retornos constantes de escala para o fator trabalho e um fator de produção específico ao respectivo setor econômico, cujo retorno é $\pi_{i}\left(p_{i}\right)$. A oferta agregada é descrita por :

(4) $X_{i}\left(p_{i}\right)=\pi^{\prime}\left(p_{i}\right)>0$, onde $\quad p_{i}$ : índice de preços ao produtor doméstico e

$$
\pi_{i}{ }^{\prime}\left(p_{i}\right) \text { representa a função derivada de } \pi_{i}\left(p_{i}\right)
$$

Supondo que a propriedade dos fatores específicos é significativamente concentrada por alguns grupos na sociedade, os proprietários de cada fator específico $i$ formam um grupo lobista com atuação junto às autoridades governamentais a fim de maximizarem seu bemestar. Para tanto, grupos lobistas rivais oferecem contribuições financeiras vinculadas à escolha governamental pela política comercial de sua preferência.

Vale salientar mais uma vez, como proposto em Baghwati (1980), que as contribuições financeiras dos grupos lobistas não devem ser interpretadas como suborno ou corrupção, mas, sim, como participação no financiamento de projetos públicos, doações ao governo destinadas a campanhas políticas ou, simplesmente, doações a fundos do governo destinados a políticas públicas favoráveis aos interesses desses grupos.

Conforme sugerido por Grossman e Helpman (1994, 1995), o governo deve optar entre o status quo (ou seja, manter as barreiras protecionistas tarifárias) e o acordo de livre comércio, maximizando uma soma ponderada entre o bem-estar social de um agente-eleitor médio (W) e o total de contribuições lobistas (C). Nesse caso, por hipótese, a função objetivo do governo é dada por:

(5) $G \equiv \sum_{i} C_{i}+a W$, onde a: parâmetro de sensibilidade do governo ao bem-estar do agente-eleitor médio relativamente às contribuições financeiras lobistas

Cada indivíduo recebe excedente do consumidor $\mathrm{S}_{\mathrm{i}}$ por consumir o bem $i$, renda do trabalho (L), lucros $(\pi)$ e transferência lump-sum do governo como uma porcentagem da receita tarifária total sobre as importações $(\mathrm{M})$, onde $\mathrm{W}$ é maximizado com $(\tau-1)$ igual a zero e, conseqüentemente, $(\tau)$ igual a um. ${ }^{9}$ Assim, o bem-estar do agente-eleitor médio é dado por:

\footnotetext{
${ }^{9}$ Ver Obstfeld e Rogoff (1998) e Krugman e Obstfeld (1997) para análise da tarifa ótima de importação no caso das pequenas economias, onde a maximização do seu bem-estar é praticar tarifa nula de importação diante de sua impossibilidade de alterar os termos de troca. Por simplificação assume-se a mesma função de bem-estar para o agente-eleitor médio da grande
} 
(6) $W=\sum_{i=1}^{n} S_{i}\left(q_{i}\right)+L+\sum_{i=1}^{n} \pi_{i}\left(p_{i}\right)+\sum_{i=1}^{n}\left(\tau_{i}-1\right) M_{i}$, onde $\tau_{i}$ : tarifa protecionista para o bem $i$

Finalmente, o grupo dos proprietários do fator específico utilizado na produção do bem $i$ recebe uma parcela insignificante do excedente do consumidor $\mathrm{S}_{\mathrm{i}}$ e das transferências lumpsum do governo. Destarte, a função objetivo de cada grupo lobista corresponde aproximadamente ao lucro líquido dado por $\pi_{\mathrm{i}}\left(\mathrm{p}_{\mathrm{i}}\right)-\mathrm{C}_{\mathrm{i}}$, sendo $\pi_{\mathrm{i}}^{\mathrm{N}}$ o lucro bruto no status quo e $\pi_{\mathrm{i}}^{\mathrm{F}}$ o lucro bruto no caso do acordo de livre comércio entre as duas economias.

Os impactos do acordo de livre comércio sobre grupos lobistas e agente-eleitor médio em cada economia dependem tanto da estrutura tarifária protecionista ex ante como da dotação de fatores de produção específicos em cada economia. No caso do bem-estar do agente-eleitor médio, vale a tradicional teoria de comércio internacional sobre criação e desvio de comércio: caso a maioria dos bens seja exportada à economia parceira no acordo de livre comércio, há um aumento do bem-estar, e, caso a maioria dos bens seja importada da economia parceira, a variação do bem-estar torna-se ambígua dependendo da magnitude dos efeitos criação e desvio de comércio. ${ }^{10}$

Com relação ao bem-estar dos grupos lobistas, como demonstrado em Grossman e Helpman (1995), produtores na economia exportadora podem ganhar e nunca perdem com o acordo de livre comércio, produtores na economia importadora podem perder e nunca ganham. Conseqüentemente, os grupos lobistas ligados ao setor exportador são favoráveis ao acordo de livre comércio, enquanto os grupos lobistas ligados ao setor importador podem oferecer alguma resistência ao acordo.

\subsection{O jogo político: primeiro estágio}

No jogo político seqüencial proposto nesta tese, no primeiro estágio os grupos lobistas das duas economias atuam de modo a influenciar as preferências unilaterais de seus respectivos governos.

economia, desprezando-se seu poder de influência sobre os termos de troca caso praticasse tarifa de importação não-nula. De qualquer forma, o modelo Grossman e Helpman (1995) apresenta uma falha estrutural na aplicação do jogo político bilateral, caso as duas economias não sejam pequenas no contexto do comércio internacional. 
Neste primeiro estágio, não há negociação entre as economias, sendo que cada governo define suas preferências unilaterais quanto ao formato do APC com base em uma maximização ponderada entre o bem-estar de seus agentes-eleitores e as contribuições financeiras dos grupos lobistas politicamente organizados. Então, uma vez definidas as preferências unilaterais dos governos, inicia-se o processo de negociação entre as economias sobre o formato do APC no segundo estágio do jogo. ${ }^{11}$

A princípio, diante da impossibilidade de exclusão de setores econômicos do APC, os governos das duas economias têm somente duas opções, a saber: status quo $(\mathrm{N})$ ou acordo preferencial de comércio (F). Nesse caso, as contribuições financeiras dos grupos lobistas podem assumir somente os valores $\mathrm{C}_{\mathrm{iN}}$ (favoráveis ao status quo) e $\mathrm{C}_{\mathrm{iF}}$ (favoráveis ao $\mathrm{APC}$ ), respectivamente.

Vale dizer que contribuições financeiras positivas para ambos os estados da natureza (especificamente, status quo e acordo preferencial de comércio) nunca representam uma estratégia ótima para um grupo lobista, já que não será possível influenciar a decisão do governo. Além disso, por hipótese, um grupo lobista nunca oferece uma contribuição financeira excessiva (ou seja, superior ao lucro vinculado à decisão comercial do governo). Por último, a fim de se eliminarem estratégias dominadas, a estratégia de oferecer contribuição financeira nula para ambos os estados da natureza fracamente domina a estratégia de oferecer uma contribuição financeira excessiva para seu estado de natureza preferido. Em resumo, as contribuições financeiras dos grupos lobistas vinculadas à preferência unilateral do governo devem ser estritamente não negativas e nunca superiores aos respectivos lucros no regime comercial escolhido. ${ }^{12}$

O governo será favorável ao acordo preferencial de comércio se, e somente se:

(7) $\sum_{i} C_{i F}+a W_{F} \geq \sum_{i} C_{i N}+a W_{N}$, onde $\mathrm{W}_{\mathrm{R}}$ : bem-estar agregado no regime $\mathrm{R}=\mathrm{N}, \mathrm{F}$

\footnotetext{
${ }^{10}$ Ver Dixit e Norman (1980).

${ }^{11}$ Na verdade, manteve-se o primeiro estágio do jogo apresentado em Grossman e Helpman (1995), cujos resultados advêm da aplicação do modelo desenvolvido por Bernheim e Whinston (1986), segundo o qual grupos de interesse oferecem um conjunto de políticas factíveis e potencialmente custosas ao governo vinculando suas contribuições financeiras às políticas realmente implementadas. Ver também Krishna (1998).

${ }^{12}$ Ver Apêndice para definições e proposições apresentadas no trabalho de Grossman e Helpman (1995).
} 
Assim, como resultado da disputa política entre grupos lobistas no primeiro estágio do jogo político, determinam-se as preferências unilaterais de cada governo com relação ao APC. Vale dizer, a preferência unilateral de cada governo refere-se ao formato do APC preferido escolhido pelo governo, caso este estivesse em condições de impor suas decisões à outra economia.

Basicamente, existem dois tipos de preferências unilaterais. As não-pressionadas referem-se às preferências unilaterais do governo por um regime comercial independentemente das contribuições financeiras dos grupos lobistas. As preferências unilaterais pressionadas dependem diretamente das contribuições financeiras dos grupos lobistas. Enquanto as unilaterais não-pressionadas prescindem das contribuições financeiras lobistas, as unilaterais pressionadas só existem em função do volume de contribuições lobistas.

Mais especificamente, existe uma preferência unilateral não-pressionada em favor do regime $\mathrm{R}$ se, e somente se, valer o resultado 8. Por outro lado, se existe uma preferência unilateral pressionada em favor do regime $\mathrm{R}$, então vale o resultado 9.

(8) $a\left(W_{R}-W_{\widetilde{R}}\right) \geq \max \left[0, \max _{i}\left(\pi_{i \widetilde{R}}-\pi_{i R}\right)\right]$

(9) $\sum_{i} \pi_{i R}+a W_{R} \geq \sum_{i} \pi_{i \widetilde{R}}+a W_{\widetilde{R}}$.

Assim, de acordo com o resultado 8, os ganhos de bem-estar pelos agentes-eleitores médios são suficientes para sustentar a preferência unilateral do governo em favor do regime de comércio R, mesmo na ausência de contribuições lobistas em prol deste regime. No entanto, caso prevaleça o resultado 9, as contribuições lobistas em prol do regime de comércio R são necessárias à definição da preferência unilateral do governo também em prol do regime de comércio R [ver proposições A.1 e A.2 de Grossman e Helpman (1995) no Apêndice desta tese].

Ainda de acordo com Grossman e Helpman (1995), caso as preferências unilaterais nãopressionadas e pressionadas sustentem regimes comerciais distintos, é razoável optar pelo regime de comércio sustentado pelas últimas. Isso porque preferências não-pressionadas não 
são sustentáveis sob a hipótese de mínima coordenação entre os grupos lobistas, conforme conceito de equilíbrio de coalition-proof desenvolvido por Bernheim et al. (1987).

O equilíbrio de coalition-proof consiste em um refinamento do equilíbrio de Nash tal que cada membro da coalizão obtém um ganho igual ou superior ao ganho associado ao equilíbrio de Nash dadas as estratégias dos não-membros da coalizão, e cada estratégia de um membro da coalizão representa a melhor reação às estratégias dos demais membros. No modelo de economia política desenvolvido por Grossman e Helpman (1995), o equilíbrio de coalitionproof seleciona uma estratégia que maximiza o bem-estar conjunto do governo e dos grupos lobistas, exigindo a validade do resultado 9 [ver proposição A.3 de Grossman e Helpman (1995) no Apêndice].

Ao término do primeiro estágio, tanto o governo da grande economia como o da pequena economia têm definidas suas preferências unilaterais com relação ao formato do APC. Vale dizer que no primeiro estágio não há negociação internacional entre as economias para a definição do formato do acordo. Portanto, as preferências unilaterais de ambos os governos refletem simplesmente os respectivos equilíbrios de coalition-proof nas duas economias.

Entretanto, ainda de acordo com Grossman e Helpman (1995), a impossibilidade de exclusão de setores politicamente sensíveis à liberalização do comércio bilateral reduz substancialmente a chance de um acordo entre a grande economia e a pequena economia para a formação de um APC. Isso porque os interesses do setor importador da grande economia diferem dos interesses do setor exportador da pequena economia e vice-versa. Neste contexto, a criação do APC exige preferências unilaterais idênticas nas duas economias.

Por outro lado, a possibilidade de ajustamento gradual ou exclusão de setores econômicos politicamente mais sensíveis do processo de liberalização tarifária inerente ao acordo representa um importante mecanismo utilizado pelo governo para reduzir a pressão de grupos lobistas contrários à formação APC. 
Deste modo, uma vez eliminada a necessidade de coincidência entre as preferências unilaterais, eleva-se a probabilidade de um APC entre a grande economia e a pequena economia. $^{13}$

O governo pode rejeitar completamente o APC (permanecendo no status quo), aceitar totalmente o APC (sem exclusão de setores econômicos) ou aceitar parcialmente o APC (com ajustamento gradual para alguns setores econômicos). ${ }^{14}$ Assim, o governo pode optar pelo status quo $(\mathrm{R}=\mathrm{N})$ ou pelo acordo de livre comércio $(\mathrm{R}=\mathrm{F})$ com um conjunto de setores temporariamente excluídos (eventualmente vazio), sendo que seu bem-estar G é maximizado comparativamente a qualquer outro regime comercial que satisfaça as regras da Organização Mundial do Comércio.

Assim, cada grupo lobista i define três contribuições financeiras $C_{i} N, C_{i} \Omega$ e $C_{i} I$, respectivamente vinculadas à preferência do governo pelo status quo, pela assinatura do APC com a exclusão do setor econômico i e pela assinatura do APC com a inclusão do setor econômico i no acordo, sendo que os setores econômicos excluídos têm um período de ajustamento para eliminação total de barreiras tarifárias. Além disso, nenhum grupo lobista pode redefinir sua estratégia de contribuição financeira dadas as estratégias dos demais grupos lobistas e suas expectativas quanto à preferência unilateral do governo.

O mecanismo de ajustamento gradual ou exclusão de setores politicamente sensíveis à concorrência externa deve obedecer a uma regra de exclusão. Considere, como sugerido em Grossman e Helpman (1995), a regra para exclusão de setores econômicos do acordo de livre comércio dada por $\int_{i \in \Omega} T_{i} d i \leq T$, onde $\Omega$ representa o conjunto de setores excluídos, $\mathrm{T}_{\mathrm{i}}$ refere-se ao tamanho do setor econômico e i e T um limite exógeno.

\footnotetext{
${ }^{13}$ Em particular, o desenvolvimento de um modelo de economia política com a possibilidade de ajustamento gradual ou exclusão de setores politicamente sensíveis ao APC torna-se muito apropriado no caso das negociações para a formação da ALCA, onde se propõe a liberalização de $85 \%$ do volume de comércio até 2015 e redução gradual das tarifas protecionistas para os $15 \%$ restantes até 2020 .

${ }^{14}$ Ao contrário de Grossman e Helpman (1995), nosso modelo não permite a exclusão ad infinitum de setores econômicos do APC, embora o aspecto temporal das negociações não seja objeto do jogo seqüencial em dois estágios desenvolvido neste trabalho. Isso porque, no atual contexto das negociações, os princípios da ALCA exigem a eliminação total das barreiras tarifárias até 2020, apenas concedendo um período de ajustamento até 2015 para aqueles setores econômicos politicamente mais sensíveis à competição externa. Destarte, em termos de bem-estar, a ALCA é menos favorável aos grupos lobistas ligados ao setor importador das economias comparativamente ao modelo teórico de Grossman e Helpman (1995), dificultando ainda mais a existência de um equilíbrio coalition-proof favorável à implementação da Área de Livre Comércio das Américas, como veremos nos próximos capítulos.
} 
Além disso, seja a classificação de todos os setores tal que $\mathrm{i} \in[0, \mathrm{n}]$ e $\mathrm{g}_{\mathrm{i}}=\left[\left(\Delta \Pi_{\mathrm{i}}+\mathrm{a} \Delta \mathrm{W}_{\mathrm{i}}\right) /\right.$ $\mathrm{T}_{\mathrm{i}}$ ], atribuindo-se $\mathrm{i}_{0}$ ao setor com menor índice tal que $\mathrm{g}_{\mathrm{i}}=0$, onde $\mathrm{g}_{\mathrm{i}}$ representa o bem-estar agregado dos grupos lobistas e do agente-eleitor médio ponderado pelo tamanho do respectivo setor econômico [ver definição A.2 de Grossman e Helpman (1995) no Apêndice].

Assim, para todos os setores econômicos pertencentes ao conjunto $\Omega(\mathrm{T})$, o ganho de bemestar conjunto do governo e dos grupos lobistas decorrente da inclusão do setor no acordo de livre comércio deve ser estritamente não-positivo e, na verdade, mais negativo do que para qualquer outro setor econômico não incluído em $\Omega(\mathrm{T})$.

Neste contexto, existem respectivamente um equilíbrio de coalition-proof e uma preferência unilateral favoráveis ao APC se, e somente se:

(10) $\int_{i \in \Omega(T)}\left(\Pi_{i N}+a W_{i N}\right) d i+\int_{i \notin \Omega(T)}\left(\Pi_{i F}+a W_{i F}\right) d i \geq \int_{i}\left(\Pi_{i N}+a W_{i N}\right) d i$

(11) $\int_{i \in \Omega(T)}\left(a W_{i N}\right) d i+\int_{i \notin \Omega(T)}\left(a W_{i F}\right) d i+C \geq \int_{i}\left(a W_{i N}\right) d i$,

onde $C=\int_{i \in \Omega(T)} \max \left[0, a\left(W_{i F}-W_{i N}\right)+\max _{j \notin \Omega(T)}\left(-T_{i} g_{i}\right)\right] d i$

Assim, o equilíbrio de coalition-proof seleciona uma estratégia que maximiza o bem-estar conjunto do governo e dos grupos lobistas, onde cada grupo lobista oferece a mesma contribuição financeira para status quo e para inclusão no conjunto $\Omega(\mathrm{T})$, todos os setores $\mathrm{j} \notin$ $\Omega(\mathrm{T})$ oferecem para a exclusão exatamente o mesmo que esperam perder por serem incluídos no acordo de livre comércio e, finalmente, todos os setores $i \in \Omega(T)$ oferecem para a exclusão no máximo o que esperam ganhar por conservarem suas barreiras tarifárias protecionistas [ver proposição A.4 de Grossman e Helpman (1995) no Apêndice].

Assim, comparativamente ao APC irrestrito (onde todos os setores econômicos têm suas barreiras tarifárias eliminadas com o início do acordo), a existência de um conjunto de setores excluídos tende a aumentar a viabilidade do APC ao permitir um período de ajustamento àqueles setores econômicos politicamente mais sensíveis. 
Naturalmente, dada a possibilidade de ajustamento ou de exclusão de setores do APC, os produtores ameaçados pela concorrência das importações têm interesse na manutenção do protecionismo nos seus respectivos setores econômicos, enquanto os produtores com perspectivas de expansão de suas exportações não têm interesse na inclusão de seus produtos na lista dos setores econômicos parcialmente excluídos do APC.

Grossman e Helpman (1995) ressaltam a importância da existência de certo "equilíbrio" nas transações comerciais entre as duas economias como fator crítico de sucesso nas negociações de um APC. Isso porque a existência de uma preferência unilateral pressionada favorável ao APC está relacionada à existência de quantidade suficiente de setores econômicos favoráveis ao acordo em ambas as economias, dispostos a contribuir financeiramente para implementação do acordo o montante suficiente para superar tanto as contribuições financeiras feitas pelos grupos lobistas ligados aos setores econômicos desfavoráveis ao APC, como a eventual perda de bem-estar social do agente-eleitor médio.

Ao término deste primeiro estágio, o equilíbrio coalition-proof seleciona uma estratégia que maximiza o bem-estar conjunto do governo e dos grupos lobistas. No entanto, o formato do acordo preferencial de comércio relaciona-se diretamente ao processo de negociação entre as duas economias com base nas respectivas preferências unilaterais definidas no primeiro estágio do jogo político seqüencial. Neste sentido, o jogo completa-se no segundo estágio com a negociação entre as duas economias para a definição do formato do APC, onde o formato refere-se especificamente ao conjunto de setores econômicos incluídos e excluídos do processo de liberalização tarifária no comércio bilateral entre as economias.

A seguir desenvolve-se o segundo estágio do jogo onde, ao contrário do processo de barganha entre duas pequenas economias desenvolvido por Grossman e Helpman (1995) ${ }^{15}$, o formato do APC define-se a partir de um jogo não-cooperativo de Stackelberg entre a grande economia e a pequena economia.

\footnotetext{
${ }^{15} \mathrm{O}$ jogo político bilateral simétrico entre duas pequenas economias proposto em Grossman e Helpman (1995), apesar das importantes contribuições à Teoria do Comércio Internacional, não se aplica aos principais acordos preferenciais de comércio da atualidade, como o NAFTA e a União Européia, nos quais uma ou mais grandes economias (Estados Unidos no primeiro exemplo, França e Alemanha no segundo) exercem seu poder de negociação de forma desproporcional ao poder de negociação das economias menores.
} 


\section{O SEGUNDO ESTÁGIO DO JOGO POLÍTICO BILATERAL}

Vale salientar que, com a substituição do jogo político simétrico de Grossman e Helpman (1995) por um jogo político não-cooperativo de Stackelberg entre economias assimétricas, são desenvolvidas novas proposições referentes ao segundo estágio do jogo político e às alterações no poder de negociação da pequena economia. Tais proposições são originais e representam a contribuição mais significativa desta tese de doutorado para a análise da economia política dos acordos preferenciais de comércio. Todas as provas são apresentadas no apêndice.

Assim, a análise da economia política de um APC completa-se com o processo de negociação entre a grande economia e a pequena economia para a definição do formato do acordo. $\mathrm{Na}$ pauta de negociações está a definição de quais setores econômicos das duas economias serão incluídos e excluídos no conjunto $\Omega(\mathrm{T})$. Como, sob a hipótese de produtos homogêneos, o fluxo de comércio de um bem é unidirecional, existem interesses conflitantes entre os grupos lobistas ligados ao setor exportador da grande economia e os respectivos grupos lobistas ligados ao setor importador da pequena economia e vice-versa. Naturalmente, os grupos lobistas ligados ao setor exportador têm interesse em não ter seus produtos inclusos no conjunto $\Omega(\mathrm{T})$, enquanto os grupos lobistas ligados ao setor importador preferem a inclusão de seus produtos em $\Omega(\mathrm{T})$.

Como os governos têm a opção de escolher entre o status quo e o APC, os ganhos de bemestar decorrentes da vigência do acordo devem ser comparados ao bem-estar político sob $\mathrm{R}=\mathrm{N}$. O APC de equilíbrio será representado pelo conjunto de indicadores $\alpha_{\mathrm{i}}$, onde $\alpha_{\mathrm{i}}=0$ para os setores i incluídos no acordo $(\mathrm{i} \in \mathrm{I})$ e $\alpha_{\mathrm{i}}=1$ para os setores i excluídos do acordo ( $\mathrm{i} \in \Omega$ ).

Assim, tanto a grande economia como a pequena economia maximizam seu bem-estar com o APC ao maximizar o lagrangeano ${ }^{16}(\Phi)$ abaixo:

(12) $\max _{\alpha_{i}}: \Phi=\log \left\{\int_{i}\left[\left(1-\alpha_{i}\right)\left(a^{J} W_{i F}^{J}+C_{i I}^{J}\right)+\alpha_{i}\left(a^{J} W_{i N}^{J}+C_{i \Omega}^{J}\right)\right] d i-\int_{i}\left(a^{J} W_{i N}^{J}+C_{i N}^{J}\right) d i\right\}-\lambda\left[\int_{i} \alpha_{i} T_{i} d i-T\right]$

\footnotetext{
${ }^{16}$ Esta função foi utilizada por Grossman e Helpman (1995) na apresentação da solução de barganha de Nash entre duas pequenas economias simétricas, sendo mantida nesta tese para efeitos de análise comparativa dos resultados do segundo estágio.
} 
Portanto, o formato do APC que resolve o processo de barganha exclui todos os setores $i \in\left[0, i^{*}\right]$, onde $i^{*}$ é definido através da ponderação entre os ganhos obtidos pelos grupos lobistas ligados ao setor exportador de uma economia e as perdas obtidas pelos grupos lobistas ligados ao setor importador da outra economia.

\subsection{O equilíbrio coalition-proof no jogo político bilateral de Stackelberg}

Nesta tese, utiliza-se esta mesma função de bem-estar para o jogo não-cooperativo de Stackelberg entre a grande economia e a pequena economia. Naturalmente, dada a significativa assimetria econômica entre a grande economia e a pequena economia, um processo de barganha torna-se irrealista sendo, por conseguinte, substituído por um jogo nãocooperativo. Não obstante, dada a possibilidade status quo, a grande economia deve ser cautelosa em sua estratégia a fim de não tornar o APC inviável para a pequena economia.

Proposição 1: Existe um equilíbrio coalition-proof para a pequena economia em um jogo não-cooperativo de Stackelberg favorável ao APC se, e somente se:

(13) $\int_{i}\left[\left(1-\alpha_{i}\right)\left(a^{J} W_{i F}^{J}+C_{i I}^{J}\right)+\alpha_{i}\left(a^{J} W_{i N}^{J}+C_{i \Omega}^{J}\right)\right] d i-\int_{i}\left(a^{J} W_{i N}^{J}+C_{i N}^{J}\right) d i=0$ para $\mathrm{J}=\mathrm{B}$, com a exclusão dos setores $i \in\left[0, i^{* *}\right]$, onde $i^{\star *} \geq 0$.

De acordo com a proposição 1, em um jogo não-cooperativo de Stackelberg a pequena economia está exatamente indiferente entre o status quo e o APC com a exclusão dos setores econômicos $i \in\left[0, i^{* *}\right]$. Neste caso, a grande economia exerce sua liderança de Stackelberg ao definir o formato do $\operatorname{APC}$ (e, portanto, o conjunto de setores incluídos em $\Omega$ ) que maximiza seus ganhos em detrimento dos eventuais ganhos da pequena economia com o APC. Isso porque a pequena economia é uma seguidora de Stackelberg e, portanto, toma como dadas as decisões da grande economia. Assim, caso os ganhos com o APC superem os ganhos no status quo, há espaço para a grande economia aumentar a lista de seus setores excluídos do acordo. Por outro lado, caso os ganhos com o APC sejam inferiores aos ganhos no status quo, a pequena economia opta pelo segundo, inviabilizando o acordo. Portanto, somente quando a pequena economia está exatamente indiferente entre o status quo e o acordo APC, tem-se o equilíbrio coalition-proof para o jogo não-cooperativo. 
Desse modo, a grande economia define o conjunto politicamente ótimo dos setores excluídos i $\in\left[0, i^{* *}\right]$ maximizando seu bem-estar, dada a função reação da pequena economia por backward induction. Além disso, como a exclusão de setores econômicos da grande economia do acordo reduz o bem-estar dos grupos lobistas exportadores da pequena economia, pode-se concluir que a função de reação da pequena economia é decrescente em relação ao número de setores econômicos da grande economia excluídos do acordo de livre comércio. Conseqüentemente, do ponto de vista da grande economia, o ganho de Stackelberg é superior ao ganho de Cournot-Nash. ${ }^{17}$

Proposição 2: Existe um equilibrio coalition-proof para a grande economia em um jogo não-cooperativo de Stackelberg favorável ao APC se, e somente se, o ganho de líder de Stackelberg for superior ao ganho Cournot-Nash.

De acordo com a proposição 2, os ganhos da grande economia associado ao APC com a exclusão dos setores $i \in\left[0, i^{* *}\right]$ são superiores ao bem-estar da grande economia em um equilíbrio de barganha de Nash onde são excluídos os setores $\mathrm{i} \in\left[0, \mathrm{i}^{*}\right]$ desenvolvido por Grossman e Helpman (1995). Caso contrário, como demonstrado em Balboa et. al. (2001), a grande economia poderia simplesmente abdicar de sua condição de líder de Stackelberg e participar de um jogo de barganha de Nash com a pequena economia.

A assimetria entre as economias reflete-se nos ganhos decorrentes do APC, com a grande economia maximizando seu bem-estar a partir da estratégia de líder de Stackelberg e a pequena economia permanecendo exatamente indiferente entre o status quo e o APC com a exclusão dos setores $i \in\left[0, i^{* *}\right]$.

\subsection{O poder de negociação da pequena economia seguidora de Stackelberg}

O modelo de economia política desenvolvido até aqui considera um jogo político seqüencial entre uma grande economia e uma pequena economia, onde as preferências unilaterais dos respectivos governos são definidas no primeiro estágio a partir da maximização de uma soma

\footnotetext{
${ }^{17}$ Vide Fudenberg e Tirole (2000), p.75
} 
ponderada entre o bem-estar do agente-eleitor médio e as contribuições lobistas, enquanto o formato do APC é definido no segundo estágio através de um jogo não-cooperativo no qual a grande economia assume o papel de líder de Stackelberg.

Nesse modelo a pequena economia pode simplesmente optar pelo status quo e o APC proposto pela grande economia. Naturalmente, no equilíbrio coalition-proof, a assimetria inerente ao jogo não-cooperativo de Stackelberg reflete-se nos ganhos das economias: o conjunto de setores econômicos pertencentes a $\Omega(\mathrm{T})$ torna a pequena economia exatamente indiferente entre o status quo e o APC, e proporciona à grande economia um ganho de bemestar superior à solução de barganha de Nash apresentada por Grossman e Helpman (1995).

Nosso objetivo será apresentar algumas modificações na estrutura inicial do jogo político que poderiam ampliar o poder de negociação da pequena economia na definição do formato do APC: a existência de oportunidades externas e a formação da coalizão com outras pequenas economias.

De um lado, a existência de oportunidades externas à pequena economia para a formação de um APC refere-se especificamente à inclusão de uma terceira economia no jogo político original, com base em Fudenberg e Levine (1989) e Fudenberg, Levine e Tirole (1987). Neste novo contexto, em função das características econômicas desta terceira economia e dos custos decorrentes do adiamento das negociações para o inicio do acordo preferencial de comércio, a pequena economia tem seu poder de negociação potencialmente elevado no jogo com a grande economia, enquanto esta última obtém ganhos potencialmente inferiores em comparação aos ganhos obtidos no equilíbrio de Stackelberg.

De outro lado, a partir do trabalho de Rosenthal (1979) e Schiff (1996), analisa-se o impacto da coalizão entre pequenas economias nas negociações com uma grande economia para a formação de um acordo preferencial de comércio sobre o poder de negociação da pequena economia comparativamente ao jogo não-cooperativo de Stackelberg. ${ }^{18}$ Conseqüentemente, o aumento do poder de negociação da pequena economia proporcionaria a inclusão de um

\footnotetext{
${ }^{18}$ Como já ressaltado anteriormente, nossa hipótese básica a respeito da coalizão entre pequenas economias consiste em argumentar que todas as pequenas economias conseguem conciliar internamente seus interesses políticos para, então, negociar com a grande economia como um único bloco, reduzindo a assimetria de poder de negociação. Trata-se de uma hipótese frágil a ser relaxada no jogo político com $\mathrm{n}$ países, onde cada pequena economia pode assumir sua própria estratégia de negociação em relação à grande economia, bem como em relação às n-2 pequenas economias.
} 
número mais elevado de seus setores econômicos no conjunto $\Omega(\mathrm{T})$, elevando seu bem-estar comparativamente ao jogo não-cooperativo de Stackelberg.

Em primeiro lugar, considere um processo de barganha entre a grande economia e a pequena economia para a formação de um APC, onde existam oportunidades externas à pequena economia. Nesse caso, a pequena economia pode interromper as atuais negociações com a grande economia e escolher negociar um outro APC com outros parceiros comerciais.

A decisão da pequena economia entre continuar o processo de barganha com a grande economia e iniciar novas negociações com outros parceiros comerciais depende, principalmente, de dois aspectos: estratégias de negociação dos potenciais parceiros comerciais e custos de adiamento (delay costs). De um lado, uma vez que a pequena economia assume o papel de seguidora de Stackelberg no jogo original, oportunidades externas oferecem condições mais favoráveis às negociações para a formação de um APC se os respectivos oponentes não forem também líderes de Stackelberg ou se as negociações com esta oportunidade externa levarem ao formato de um APC mais favorável à pequena economia. Por outro lado, na presença de custos de adiamento, a pequena economia torna-se menos propensa a encerrar as negociações com a grande economia e buscar oportunidades externas.

Naturalmente, a pequena economia prefere ter à disposição inúmeras oportunidades externas, enquanto a grande economia prefere que não exista à pequena economia qualquer oportunidade externa. Isso porque a existência de oportunidades externas eleva o poder de negociação da pequena economia no processo de barganha com a grande economia para a formação de um APC.

Proposição 3: (sem custos de adiamento) Dada a existência de oportunidades externas à pequena economia, existe um equilíbrio coalition-proof favorável ao acordo de livre comércio com a grande economia se, e somente se:

(14) $\int_{i}\left[\left(1-\alpha_{i}\right)\left(a^{A B} W_{i F}^{A B}+C_{i I}^{A B}\right)+\alpha_{i}\left(a^{A B} W_{i N}^{A B}+C_{i \Omega}^{A B}\right)\right] d i-\int_{i}\left(a^{A B} W_{i N}^{A B}+C_{i N}^{A B}\right) d i=\Psi e$ 
(15) $\Psi \geq \max \left\{0,\left[\int_{i}\left[\left(1-\alpha_{i}\right)\left(a^{C B} W_{i F}^{C B}+C_{i I}^{C B}\right)+\alpha_{i}\left(a^{C B} W_{i N}^{C B}+C_{i \Omega}^{C B}\right)\right] d i-\int_{i}\left(a^{C B} W_{i N}^{C B}+C_{i N}^{C B}\right) d i\right]\right\}$ com a exclusão dos setores $i \in\left[0, i^{\delta}\right], i^{\delta}>0$, onde: AB refere-se ao acordo de livre comércio entre a pequena economia e a grande economia, e CB ao acordo da pequena economia com o novo parceiro comercial.

Assim, conforme proposição 3, dada a possibilidade de trocar de oponente sem custos de adiamento, a grande economia (líder de Stackelberg) define um novo formato para o APC, oferecendo à pequena economia um ganho estritamente não negativo (e, portanto, potencialmente superior ao bem-estar no equilíbrio de Stackelberg) e, no mínimo, idêntico aos ganhos da pequena economia decorrentes do acordo CB com a oportunidade externa. O novo conjunto de setores excluídos do acordo $\mathrm{i} \in\left[0, \mathrm{i}^{\delta}\right]$ proporciona um ganho potencialmente superior à pequena economia comparativamente aos ganhos decorrentes do APC com a exclusão dos setores econômicos $i \in\left[0, i^{* *}\right]$.

Na presença de custos de adiamento, reduz-se o ganho da pequena economia decorrente da existência de oportunidades externas. Não obstante, comparativamente ao jogo nãocooperativo de Stackelberg, a pequena economia ainda é capaz de elevar seu poder de negociação em relação à grande economia.

Proposição 4: (com custos de adiamento) Dada a existência de oportunidades externas à pequena economia, existe um equilíbrio coalition-proof favorável ao APC com a grande economia se, e somente se:

(16) $\int_{i}\left[\left(1-\alpha_{i}\right)\left(a^{A B} W_{i F}^{A B}+C_{i I}^{A B}\right)+\alpha_{i}\left(a^{A B} W_{i N}^{A B}+C_{i \Omega}^{A B}\right)\right] d i-\int_{i}\left(a^{A B} W_{i N}^{A B}+C_{i N}^{A B}\right) d i=\Psi$ e

(17) $\Psi \geq \max \left\{0,\left[\int_{i}\left[\left(1-\alpha_{i}\right)\left(a^{C B} W_{i F}^{C B}+C_{i I}^{C B}\right)+\alpha_{i}\left(a^{C B} W_{i N}^{C B}+C_{i \Omega}^{C B}\right)\right] d i-\int_{i}\left(a^{C B} W_{i N}^{C B}+C_{i N}^{C B}\right) d i\right]-D\right\}$ com a exclusão dos setores $i \in\left[0, i^{\theta}\right], i^{\theta}>0$, onde: $D$ representa o custo de adiamento nas negociações para a formação de um APC.

Naturalmente, conforme proposição 4, na presença de custos de adiamento, a pequena economia torna-se menos propensa a buscar oportunidades externas. Não obstante, o 
conjunto de setores excluídos do APC com a grande economia $\mathrm{i} \in\left[0, \mathrm{i}^{\theta}\right]$ ainda proporciona ganhos potencialmente superiores ao APC com exclusão dos setores econômicos $i \in\left[0, i^{* *}\right]$.

Portanto, conclui-se que a existência de oportunidades externas à pequena economia aumenta tanto seu poder de negociação como seus ganhos comparativamente ao jogo não-cooperativo de Stackelberg. Por exemplo, as negociações entre Brasil e União Européia para a formação de uma área de livre comércio podem elevar potencialmente o poder de negociação brasileiro nas negociações com os Estados Unidos para a formação da Área de Livre Comércio das Américas.

Em segundo lugar, conforme destacado por Schiff (1996), em um processo de barganha entre pequenas economias e uma grande economia para a formação de um APC, as pequenas economias podem elevar seu poder de negociação ao adotar uma estratégia conjunta. Obviamente, os ganhos de comércio estão associados à redução da assimetria no poder de negociação entre os oponentes. Isso porque o conjunto $\Omega(\mathrm{T})$ que torna a coalizão indiferente entre o status quo e o APC pode ser mais favorável à pequena economia comparativamente ao conjunto $\Omega(\mathrm{T})$ definido anteriormente no jogo bilateral de Stackelberg.

Neste caso, como descrito pela proposição 5, considere uma grande economia envolvida em diversas negociações para a formação de diferentes APCs com pequenas economias. Caso as negociações prossigam de forma isolada, a grande economia obtém o ganho de líder de Stackelberg em todos os acordos, enquanto todas as pequenas economias permanecem exatamente indiferentes entre o status quo e o APC.

Proposição 5: Seja uma grande economia envolvida em negociações isoladas com diversas pequenas economias $j=1, \ldots, N$ para a formação de diversos APCs. Então, caso não haja coalizão entre as pequenas economias, o APC que resolve o processo de barganha exclui todos os setores $i_{j} \in\left[0, i_{j}{ }^{j}\right]$, onde $i_{j}{ }^{j} e^{j}$ definido através da ponderação entre as perdas e os ganhos obtidos pelos grupos lobistas da grande economia e das pequenas economias. Neste caso, a grande economia obtém o ganho de líder de Stackelberg em todas as negociações, enquanto cada pequena economia permanece exatamente indiferente entre o status quo e o APC. 
No entanto, conforme proposição 6 , as pequenas economias podem elevar potencialmente seus ganhos decorrentes do APC através da formação de uma coalizão para as negociações bilaterais com a grande economia comparativamente ao ganho de seguidora de Stackelberg. Isso porque, como membro de uma coalizão de pequenas economias, a pequena economia $\mathrm{A}$ reduz a assimetria em relação à grande economia $\mathrm{B}$, sem incorrerem em custos adicionais decorrentes do processo de negociação com as demais pequenas economias. ${ }^{19}$

Proposição 6: Seja uma grande economia envolvida em negociações isoladas com diversas pequenas economias $j=1, \ldots, N$ para a formação de diversos APCs. Então, caso haja coalizão entre as pequenas economias que resulte em uma única posição unilateral para o primeiro estágio do jogo, o APC que resolve o processo de barganha exclui todos os setores $i \in\left[0, i^{\tau}\right]$, onde $i^{\tau} e^{e}$ definido através da ponderação entre as perdas e os ganhos obtidos pelos grupos lobistas da grande economia e das pequenas economias. Neste caso, a grande economia obtém um ganho igual ou inferior ao ganho de líder de Stackelberg, enquanto os ganhos decorrentes da formação da coalizão superam os ganhos de seguidora de Stackelberg.

Vale salientar que a estratégia lobista definida na coalizão segue o mesmo processo backward induction utilizado na estratégia lobista para o jogo de Stackelberg. Isso porque, ao contrário da preferência unilateral da respectiva economia, a preferência unilateral da coalizão está além do poder de influência dos grupos lobistas, restritos à atuação nacional. Portanto, no caso de uma coalizão entre pequenas economias com atividades econômicas distintas, pode-se argumentar que a estratégia coalizão dificilmente será um equilíbrio coalition-proof, dadas a existência de conflitos de interesses lobistas e a impossibilidade de uma estratégia comum a todas as preferências unilaterais.

Portanto, comparativamente ao jogo não-cooperativo de Stackelberg, a pequena economia pode elevar seu poder de negociação no processo de barganha com a grande economia em duas situações, a saber: existência de oportunidades externas à pequena economia e formação

${ }^{19} \mathrm{Na}$ realidade existem custos aos países envolvidos em um processo de negociação para a formação de acordos preferenciais de comércio. Não obstante, tais custos são predominantemente diplomáticos e, portanto, existem independentemente das negociações internacionais entre as duas economias para a formação de um acordo preferencial de comércio em particular. Elimina-se, portanto, a possibilidade de free-rider em uma coalizão. 
de uma coalizão entre pequenas economias. De um lado, a decisão da pequena economia entre continuar o processo de barganha com a grande economia e iniciar novas negociações com outros parceiros comerciais depende, principalmente, das estratégias de negociação dos potenciais parceiros comerciais e dos custos de adiamento. De outro lado, a formação de uma coalizão entre pequenas economias reduz a assimetria econômica em relação à grande economia, elevando os ganhos da pequena economia decorrentes do APC.

O jogo político bilateral seqüencial de Stackelberg apresenta algumas conclusões muito interessantes sobre o formato e a viabilidade política de um APC entre duas economias significativamente assimétricas quanto ao seu poder de negociação internacional. Em primeiro lugar, assim como em Grossman e Helpman (1995) e Krishna (1998), o modelo apresenta a importância da atuação política coordenada dos setores econômicos para a definição da política comercial do governo. Em segundo lugar, o modelo aponta a estratégia vencedora do líder de Stackelberg para maximizar seus ganhos em detrimento da pequena economia, que, no entanto, ainda tem interesse em aderir ao APC. Finalmente, o modelo permite algumas modificações no formato do segundo estágio do jogo com o objetivo de aumentar o poder de barganha da pequena economia.

Naturalmente, o jogo político não-cooperativo entre apenas duas economias não esgota todas as possibilidades em torno das negociações para formação de acordos preferenciais de comércio de modo geral e, em particular, para criação da Área de Livre Comércio das Américas entre 34 países. No próximo capítulo, com base em Fudenberg e Kreps (1987), Fudenberg e Levine (1989) e Mailath e Postlewaite (1990), ampliam-se os resultados do jogo político não-cooperativo de Stackelberg entre apenas duas economias para um processo de negociação entre n economias, com o objetivo de analisar a viabilidade política da ALCA.

Neste caso, o primeiro estágio é idêntico ao proposto em Grossman e Helpman (1995) em todas as n economias, sendo uma grande economia e n-1 pequenas economias com tamanhos, pressões políticas e interesses econômicos distintos. No segundo estágio, a grande economia assume a posição de liderança de Stackelberg em negociações simultâneas com as n-1 pequenas economias, que, por sua vez, também negociam entre si, em um total de $S n$ (ou seja, a soma de uma progressão aritmética com $n$ termos) negociações simultâneas, onde cada uma das $\mathrm{n}$ economias tem igual poder de veto sobre o APC, e todas as decisões devem ser 
consenso entre as n economias. Mais uma vez, a variável de escolha é o conjunto de setores econômicos excluídos e incluídos do APC.

Comparam-se os resultados deste modelo com $\mathrm{n}$ economias em relação aos resultados decorrentes do modelo bilateral, demonstrando-se, com base em Mailath e Postlewaite (1990), a crescente dificuldade na obtenção de um APC politicamente viável para as n economias à medida que n aumenta. Então, de acordo com Grossman e Helpman (1995), o modelo permite analisar o papel das contribuições financeiras estrangeiras de grupos lobistas de uma economia para os governos das outras economias. Por último, inclui-se a possibilidade de transferências compensatórias entre os governos ao longo do segundo estágio, como mecanismo de incentivo às economias (leia-se governos) potencialmente contrárias ao APC. 


\section{A ECONOMIA POLÍTICA DA ALCA: O JOGO POLÍTICO COM N PAÍSES}

O jogo político não-cooperativo de Stackelberg entre uma grande economia e uma pequena economia simplifica sobremaneira o processo de negociação para a formação de um APC entre $\mathrm{n}$ países, aglutinando todos os interesses políticos e econômicos em apenas dois jogadores.

$\mathrm{Na}$ análise da economia política da ALCA — com seus princípios básicos "adoção de decisões por consenso; igualdade soberana dos países; (...)" [ALCA (2004)] —, o jogo político bilateral é substituído por um jogo não-cooperativo entre n países com igual poder de veto sobre o formato do APC.

Qual a viabilidade política e econômica de um acordo preferencial de comércio entre n países com igual poder de veto? Qual o formato das negociações entre n países com tamanhos e interesses econômicos tão distintos? Quais as regras para exclusão de setores econômicos de um acordo preferencial de comércio envolvendo n países?

Neste capítulo, essas questões serão abordadas com base em quatro diferentes estruturas para o processo de negociação entre $n$ países. Inicialmente, recuperam-se novamente algumas conclusões apresentadas em Grossman e Helpman (1995) para a formatação de um jogo de barganha política envolvendo $\mathrm{n}$ jogadores, incluindo ou não a possibilidade de contribuições internacionais por parte dos grupos lobistas. Então, propõe-se mais uma vez a aplicação de um jogo político não-cooperativo de Staceklberg para $\mathrm{n}$ países, incluindo ou não a possibilidade de transferências compensatórias entre governos. Trata-se da contribuição final desta tese de doutorado à literatura de economia política aplicada a acordos preferenciais de comércio.

Inicialmente, apresentam-se alguns fatos estilizados sobre os países envolvidos na negociação para a criação da ALCA. Na verdade, a análise da economia política da ALCA foi a motivação para esta tese de doutorado, cujas conclusões não esgotam sua complexidade, inserida no contexto do novo regionalismo descrito em Ethier (1998). ${ }^{20}$

\footnotetext{
${ }^{20}$ Vide apêndice para um breve resumo da estrutura de negociação da ALCA. Ver também FTAA (2001).
} 


\subsection{ALCA: fatos estilizados ${ }^{21}$}

A Área de Livre Comércio das Américas tem como característica peculiar a diversidade de seus participantes em termos de indicadores econômicos, estrutura comercial e atividades produtivas. $^{22}$ Nenhum outro acordo preferencial de comércio - nem mesmo União Européia e NAFTA - engloba economias tão heterogêneas. ${ }^{23}$

Além disso, embora represente uma sobreposição sobre diversos acordos preferenciais de comércio menores já existentes, tais como Mercosul e NAFTA, a ALCA não se resume à simples criação de uma nova área de livre comércio mais ampla onde apenas são eliminadas as barreiras comerciais entre os países-membros, mas aborda temas complexos como direitos de propriedade intelectual e políticas de competição. ${ }^{24}$

Inicialmente, nesta tese a modificação do jogo de barganha política bilateral de Grossman e Helpman (1995) para um jogo bilateral não-cooperativo de Stackelberg reconhece a supremacia exercida pelos Estados Unidos no continente americano, definindo o Brasil como a economia seguidora de Stackelberg. No caso brasileiro, a inclusão do país no jogo como a pequena economia justificou-se tanto pela posição de liderança assumida pelo Brasil na América Latina quanto pelo alinhamento de Canadá e México à estratégia comercial norteamericana definida no âmbito do NAFTA.

Neste capítulo, fica notória a limitação do jogo político bilateral diante da complexidade de um acordo preferencial de comércio negociado entre vários países social, política e economicamente distintos, como no caso particular da ALCA. Destarte, desenvolve-se um jogo político com n países, com uma grande economia e n-1 pequenas economias.

\footnotetext{
${ }^{21}$ Vale salientar que, conforme tipologia dos acordos preferenciais de comércio definida pela OMC, a ALCA é um acordo de livre comércio, onde são eliminadas as barreiras protecionistas entre os países membros do acordo, sem necessidade de alteração das respectivas estruturas tarifárias em relação aos países não-membros do acordo. Neste sentido, trata-se de um acordo preferencial de comércio mais limitado comparativamente a uniões aduaneiras (onde, além da liberalização tarifária intra-bloco, define-se uma tarifa externa comum em relação aos países não-membros), mercado comum (onde há plena liberalização das barreiras protecionistas contra o fluxo de mercadorias e plena mobilidade de fatores de produção entre os países membros, e a definição de uma tarifa externa comum) e união monetária (mercado comum com a implementação de uma moeda única).

${ }^{22}$ Ver USTR - United States Trade Representative (2001).

${ }^{23}$ Ver Abreu (1995), Pereira (1997) e Carvalho e Parente (1999) para estudos sobre os impactos da ALCA no Brasil.

${ }^{24} \mathrm{Na}$ verdade, a ALCA insere-se na definição de novo regionalismo proposta por Ethier (1998), segundo a qual os ganhos de bem-estar decorrentes da implementação do acordo preferencial de comércio substituem os tradicionais efeitos perversos de desvio de comércio inerentes à abordagem de Viner (1950). Resumidamente, ainda de acordo com Ethier (1998), o novo
} 
A Tabela 1 apresenta as principais barreiras tarifárias às exportações brasileiras impostas pelos principais parceiros comerciais do país no final da década de 1990. É possível observar que Estados Unidos e União Européia apresentavam as menores tarifas médias, mas os Estados Unidos apresentavam os maiores picos tarifários.

\begin{tabular}{|c|c|c|c|c|c|}
\hline \multicolumn{6}{|c|}{ Tabela 1 : Barreiras tarifárias às exportações brasileiras } \\
\hline & Estados Unidos & União Européia & Canadá & México & Chile \\
\hline Tarifa média (\%) & 5.15 & 5.95 & 7.51 & 13.26 & 10.96 \\
\hline Desvio padrão (\%) & 11.75 & 5.60 & 26.55 & 13.45 & 0.66 \\
\hline Máxima (\%) & 350.00 & 88.90 & 341.00 & 260.00 & 11.00 \\
\hline Mínima (\%) & 0.00 & 0.00 & 0.00 & 0.00 & 0.00 \\
\hline $\begin{array}{l}\text { Picos tarifários } \\
\text { (número de itens) }\end{array}$ & 12 & 25 & 90 & 43 & 0 \\
\hline \multicolumn{6}{|c|}{ Freqüência relativa no intervalo tarifário (em\%) } \\
\hline 0 & 21.35 & 17.62 & 45.93 & 14.68 & 0.36 \\
\hline 0 -----| 10 & 64.89 & 61.78 & 39.00 & 37.96 & 0.00 \\
\hline 10 -----| 15 & 11.68 & 14.30 & 4.63 & 25.76 & 99.64 \\
\hline 15 ----- 30 & 1.42 & 5.74 & 0.08 & 16.75 & $\ldots$ \\
\hline 30 ---- 50 & 0.53 & 0.54 & 0.01 & 4.26 & $\ldots$ \\
\hline 50 -----| 100 & 0.02 & 0.02 & 0.03 & 0.24 & $\ldots$ \\
\hline 100 ----- 150 & 0.03 & $\ldots$ & 0.01 & 0.10 & $\ldots$ \\
\hline 150 -----| 200 & 0.02 & $\ldots$ & 0.26 & 0.15 & $\ldots$ \\
\hline 200 ----- 250 & 0.02 & $\ldots$ & 0.10 & 0.10 & $\ldots$ \\
\hline 300 & 0.02 & $\ldots$ & 0.73 & $\ldots$ & $\ldots$ \\
\hline 300 ----- 350 & 0.03 & $\ldots$ & 0.06 & . .. & $\ldots$ \\
\hline Fonte : FUNCEX (1999 & $A(2001)$ & & & & \\
\hline
\end{tabular}

Além disso, como demonstrado na Tabela 2, a atuação coordenada de grupos lobistas nos Estados Unidos junto ao USTR tem sido uma prática disseminada nos diversos setores econômicos, que, no caso específico da ALCA, concentrou-se na pressão por rápida eliminação das barreiras tarifárias entre os países-membros e na implementação de direitos compensatórios e medidas antidumping contra práticas desleais de comércio. Como demonstrado em Hillman (1982), os grupos lobistas mais ativos nos Estados Unidos estão ligados a setores econômicos em decadência ou com baixa competitividade internacional.

regionalismo envolveria participação de pequenas e grandes economias, realização de significativas reformas estruturais nos 


\section{Tabela 2: A atuação dos principais grupos lobistas norte-americanos}

$\begin{array}{lccc}\text { Produto } & \begin{array}{c}\text { Faturamento anual } \\ \text { do setor } \\ \text { (US\$ bilhões) }\end{array} & \begin{array}{c}\text { Atuação } \\ \text { no Congresso }\end{array} & \begin{array}{c}\text { Contribuição em } \\ \text { campanhas lobistas } \\ \text { para o Congresso } \\ \text { entre 1990 e 2000 }\end{array} \\ \text { tabaco } & 1,09 & \text { ativa } & \text { US\$ 37,9 milhões } \\ \text { milho } & 17 & \text { muito ativa } & \text { US\$ 10 milhões } \\ \text { açúcar } & 1,86 & \text { muito ativa } & \text { US\$ 15 milhões } \\ \text { suco de laranja } & 1,75 & \text { pouco ativa } & \text { US\$ 3 milhões } \\ \text { aço } & 75 & \text { muito ativa } & \text { US\$ } 8,7 \text { milhões } \\ \text { aves } & 15 & \text { ativa } & \text { US\$ } 6 \text { milhões }\end{array}$

Fonte: Gazeta Mercantil (2001)

Tabela 3: Comércio bilateral Brasil versus Estados Unidos

Capítulo do Sistema Harmonizado

Brasil

Animais vivos e produtos do reino vegetal

Produtos do reino vegetal

Gorduras e óleos animais e vegetais

Produtos alimentícios, bebidas e vegetais

Produtos minerais

Produtos das indústrias químicas

Plásticos, borracha e suas obras

Peles, couros e suas obras

Madeira e suas obras

Pasta de madeira, papel e suas obras

Matérias têxteis e suas obras

Calçados, chapéus e semelhantes

Obras de pedra, cimento e semelhantes

Pérolas naturais, pedras preciosas

Metais comuns e suas obras

Máquinas e aparelhos elétricos

Material de transporte

Instrumentos e aparelhos de óptica

Armas e munições e suas partes

Mercadorias e produtos diversos

Objetos de arte e antigüidades

Total
Importações Brasil
Total da $\quad \%$ EUA

pauta

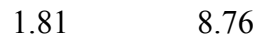

4.21

0.48

1.52

12.19

16.76

4.74

0.38

0.13

2.15

2.96

0.14

0.69

0.28

4.41

33.62

9.14

3.56

0.07

0.77

0.01

100.00

US\$ 59,73 bilhões

7.18

7.47

13.09

11.10

29.21

28.81

3.28

8.30

31.14

12.05

3.64

23.16

5.95

25.75

27.90

15.84

37.12

4.51

20.55

3.68

24.41
Importações EUA

Total da \%

pauta

1.31

0.01

100.00
1.11

0.06

0.00

0.07

0.05

0.05

0.03

0.01

0.05

0.04

0.02

0.09

0.02

0.04

0.22

0.18

0.17

0.01

0.00

$\begin{array}{ll}4.08 & 0.01 \\ 3.54 & 0.04\end{array}$

$\begin{array}{ll}4.08 & 0.01 \\ 3.54 & 0.04\end{array}$

US\$870,43 bilhões

Fonte: FUNCEX (1999); WorldBank (2001) 
Finalmente, a Tabela 3 apresenta a assimetria nas relações comerciais entre Brasil e Estados Unidos no final da década de 1990, período em que se iniciam as negociações para formação da ALCA. Enquanto as exportações brasileiras respondiam por apenas $1,11 \%$ da pauta de importações norte-americanas, os Estados Unidos respondiam por $24,41 \%$ da pauta de importações brasileira. Tal assimetria reforça a significativa diferença entre o poder econômico do Brasil e o dos Estados Unidos, justificando a aplicação de uma estrutura nãocooperativa de Stackelberg na análise da economia política da ALCA. Vide Kume e Piani (2005).

Assim, enquanto as Tabelas 1 e 2 apresentam a estrutura tarifária protecionista vigente no continente americano e a forte atuação lobista nos Estados Unidos, a Tabela 3 reflete a assimetria nas relações comerciais entre dois dos principais países do continente, Estados Unidos e Brasil.

Em seguida, desenvolve-se o jogo político não-cooperativo de Stackelberg com n países, com o objetivo de analisar a economia política de um APC, onde cada país tem igual poder de veto sobre as cláusulas do acordo.

\subsection{O jogo de barganha de Nash com n jogadores: variações do modelo Grossman e Helpman}

Grossman e Helpman (1995) desenvolvem um jogo de barganha de Nash para definição da viabilidade e do formato de um APC entre duas pequenas economias com alguma simetria nos fluxos comerciais bilaterais. No primeiro estágio do jogo, grupos lobistas ligados a setores exportadores apoiariam financeiramente a entrada do país no APC, enquanto grupos lobistas ligados a setores importadores estariam dispostos a desembolsar contribuições financeiras para inviabilizar a entrada do país no acordo ou, em um modelo mais amplo, serem inclusos no conjunto de setores econômicos excluídos da liberalização das barreiras tarifárias inerentes ao acordo. O governo definiria sua posição unilateral com base na maximização ponderada do 
bem-estar do agente eleitor médio e das contribuições dos grupos lobistas pró e contra o APC. O equilíbrio coalition-proof ${ }^{25}$ neste primeiro estágio é dado pela equação 18 :

$$
\int_{i \in \Omega(T)}\left(\Pi_{i N}+a W_{i N}\right) d i+\int_{i \notin \Omega(T)}\left(\Pi_{i F}+a W_{i F}\right) d i \geq \int_{i}\left(\Pi_{i N}+a W_{i N}\right) d i
$$

No segundo estágio, como descrito pela equação 19, a possibilidade de exclusão de setores econômicos do APC torna-se alvo do processo de barganha internacional entre as duas economias. $^{26}$

(19) $\max _{\alpha_{i}}: \Phi=\log \left\{\int_{i}\left[\left(1-\alpha_{i}\right)\left(a^{J} W_{i F}^{J}+C_{i I}^{J}\right)+\alpha_{i}\left(a^{J} W_{i N}^{J}+C_{i \Omega}^{J}\right)\right] d i-\int_{i}\left(a^{J} W_{i N}^{J}+C_{i N}^{J}\right) d i\right\}-\lambda\left[\int_{i} \alpha_{i} T_{i} d i-T\right]$

Neste momento, sendo $J=A, B$, a economia com maior poder de negociação internacional excluiria a maior parte de seus setores importadores mais sensíveis à liberalização das barreiras protecionistas, conforme condições de primeira ordem à maximização da equação 19 descritas abaixo:

(20) $\sum_{J=A, B} \frac{\beta^{J}}{G^{J}-\bar{G}^{J}}\left[\frac{\left(a^{J} W_{i F}^{J}+C_{i I}^{J}\right)-\left(a^{J} W_{i N}^{J}+C_{i \Omega}^{J}\right)}{T_{i}}\right] \geq-\lambda$, para $\alpha_{i}=0$

(21) $\sum_{J=A, B} \frac{\beta^{J}}{G^{J}-\bar{G}^{J}}\left[\frac{\left(a^{J} W_{i F}^{J}+C_{i I}^{J}\right)-\left(a^{J} W_{i N}^{J}+C_{i \Omega}^{J}\right)}{T_{i}}\right] \leq-\lambda$, para $\alpha_{i}=1$

onde, $\bar{G}^{J} \equiv \int\left(a^{J} W_{i N}^{J}+C_{i N}^{J}\right)$ di refere-se ao bem-estar politico do governo $J$ no status quo, $e$

$G^{J} \equiv \int_{i \in \Omega}\left(a^{J} W_{i N}^{J}+C_{i \Omega}^{J}\right) d i+\int_{i \notin \Omega}\left(a^{J} W_{i F}^{J}+C_{i I}^{J}\right) d i$ equivale ao equilibrio de barganha de Nash ao país $J$.

Assim, conforme descrito em Grossman e Helpman (1995) e já ressaltado no capítulo 4 deste trabalho, o APC que resolve o processo de barganha entre duas pequenas economias exclui

\footnotetext{
${ }^{25}$ Vide equação 10.

${ }^{26}$ Vide equação 12 .
} 
todos os setores $i \in\left[0, i^{*}\right]$, onde $i^{*}$ é definido através da ponderação entre os ganhos obtidos pelos grupos lobistas ligados ao setor exportador de uma economia e as perdas obtidas pelos grupos lobistas ligado ao setor importador da outra economia.

O modelo é perfeitamente aplicável ao jogo de barganha bilateral. Não obstante, a pergunta central implícita na aplicação desse modelo à análise da economia política da ALCA é a seguinte: é possível tal processo de barganha envolvendo $\mathrm{n}$ economias resultar em um equilíbrio de Nash favorável à implementação do acordo preferencial de comércio? As equações 20 e 21 produzem um equilíbrio de Nash no caso de n economias com tamanhos diferentes?

Paralelamente, apesar da assimetria relacionada ao poder de negociação ser potencialmente mensurada pelos pesos de Nash ( $\beta$ ), no caso específico da ALCA, surge outra pergunta central: por que uma grande economia como os Estados Unidos optaria por um processo de barganha de Nash, caso pudesse exercer sua liderança de Stackelberg e, assim, maximizar o bem-estar político do seu governo e dos seus grupos lobistas?

Grossman e Helpman (1995) apontam a existência de certa simetria nos fluxos comerciais bilaterais como fator crítico ao sucesso das negociações internacionais favoráveis à criação de um APC. O raciocínio lógico apenas enfatiza a importância de existirem, em cada economia, grupos lobistas ligados ao setor exportador, cujas contribuições financeiras ao governo superem o lobby contrário ao acordo promovido pelas contribuições financeiras feitas pelos grupos lobistas ligados ao setor importador.

É fácil argumentar, como destacado em Abreu (1995), sobre a inexistência de tal simetria nos fluxos comerciais entre todos os países candidatos à Área de Livre Comércio das Américas. De um lado, os países-membros do NAFTA apresentam certa simetria nos fluxos comerciais entre si, embora tal simetria não seja verificada no comércio desses países com os países da América Central e da América do Sul. De outro lado, os países da América Central apresentam certo equilíbrio nos fluxos comerciais entre si, mas novamente não se observa tal simetria nas relações comerciais entre esses países e os países da América do Sul. É plausível 
supor que o processo de barganha de Nash encontrará um equilíbrio internacional, cujo conjunto de setores excluídos da liberalização tarifária prevista na ALCA será idêntico em economias tão distintas?

Com o objetivo de ilustrar a real dificuldade em implementar um APC entre tantas economias com seus respectivos tamanhos, setores econômicos, grupos lobistas e interesses políticos, adotemos uma hipótese restritiva sobre as regras a serem seguidas na definição dos setores econômicos excluídos do acordo. Todas as 34 economias têm igual poder de veto, e todas as decisões devem ser tomadas em consenso. Todos os setores econômicos são organizados conforme critérios de classificação do Sistema Harmonizado ${ }^{27}$, assim totalizando 21 setores econômicos diferentes. Vide Figura 1.

\begin{tabular}{|c|c|c|c|c|c|c|c|c|c|c|}
\hline \multicolumn{11}{|c|}{ Figura 1: Sistema harmonizado de comércio na ALCA } \\
\hline & \multicolumn{10}{|c|}{ Economias } \\
\hline & & $\mathbf{A}$ & B & $\mathbf{C}$ & $\mathbf{D}$ & $\mathbf{E}$ & $\mathbf{F}$ & G & ... & $\mathbf{n}$ \\
\hline & I & ia & $\mathrm{ib}$ & ic & id & ie & if & ig & .. & in \\
\hline & II & iia & iib & iic & iid & iie & iif & iig & .. & iin \\
\hline \multirow[t]{3}{*}{ Setores } & III & iiia & iiib & iiic & iiid & iiie & iiif & iiig & $\ldots$ & iiin \\
\hline & $\cdots$ & $\cdots$ & $\cdots$ & $\cdots$ & $\cdots$ & $\cdots$ & $\cdots$ & $\cdots$ & $\cdots$ & $\cdots$ \\
\hline & $\mathbf{s}$ & as & $\mathrm{sb}$ & $\mathrm{sc}$ & sd & se & sf & $\mathrm{sg}$ & $\ldots$ & sn \\
\hline \multirow[t]{3}{*}{ onde, } & \multicolumn{10}{|c|}{ s: número de setores classificados conforme Sistema Harmonizado } \\
\hline & \multicolumn{10}{|c|}{ x: quantidade de setores excluídos do acordo preferencial de comércio ALCA } \\
\hline & & $10 \mathrm{c}$ & onom & תו1 & a & goct & aia & & & \\
\hline
\end{tabular}

Nosso objetivo será calcular a probabilidade da criação de um APC politicamente viável em todas as economias, inclusive com a exclusão de alguns setores econômicos do processo de eliminação das barreiras protecionistas. Para tanto, assumiremos que todas as economias têm todos os setores econômicos classificados no Sistema Harmonizado e que, inicialmente, no

${ }^{27}$ Vide USCBP - U.S. Customs and Border Protection (2004). 
processo de negociação internacional com as demais economias, cada governo escolhe aleatoriamente um único setor econômico a ser excluído do APC. ${ }^{28}$

Observa-se que a probabilidade de a economia A selecionar aleatoriamente o setor I para o conjunto de setores excluídos do acordo preferencial de comércio é igual 1/s. Sob a hipótese inicial de que todos os setores são política e economicamente importantes em todas as economias, a probabilidade de o setor I ser aleatoriamente selecionado em todas as economias equivale a $(1 / \mathrm{s})^{\mathrm{n}}$.

Do mesmo modo, caso cada economia tenha o direito de selecionar aleatoriamente dois setores econômicos para o conjunto de setores excluídos do APC, a probabilidade da economia A selecionar aleatoriamente os setores I e II equivale a $(1 / s)^{2}$. É fácil concluir que a probabilidade dos setores I e II serem aleatoriamente selecionados em todas as n economias totaliza $(1 / \mathrm{s})^{2 \mathrm{n}}$.

Portanto, conclui-se que a probabilidade de x setores econômicos serem excluídos do APC por uma decisão de consenso entre todas as economias envolvidas no processo de barganha internacional equivale a $(1 / \mathrm{s})^{\mathrm{xn}}$, decrescente com o aumento do número de setores classificados no Sistema Harmonizado (s), número de economias-membro do APC (n) e número de setores excluídos do processo de liberalização das barreiras protecionistas (x).

Supondo que todos os 34 países envolvidos nas negociações da ALCA pudessem escolher aleatoriamente, dentre os 21 setores classificados no Sistema Harmonizado, apenas 5 setores a serem excluídos do acordo, a probabilidade de a ALCA ser política e economicamente viável conforme as regras descritas neste exemplo seria $(1 / 21)^{170}=1,67 * 10^{-225}$, ou seja, a viabilidade política da ALCA com apenas cinco setores excluídos seria praticamente nula.

\footnotetext{
${ }^{28}$ Ignora-se neste momento se tal escolha do governo esteve relacionada à pressão dos grupos lobistas relacionados a este setor econômico. Na verdade, para efeitos de cálculo de probabilidade desse exemplo, preferiu-se simplificar ao máximo a definição da posição unilateral de cada governo, sem prejuízos à conclusão do exemplo. Nosso objetivo neste momento foi apenas ilustrar a baixa probabilidade de um acordo preferencial de comércio ser politicamente viável a tantas economias tão díspares em termos de economia, política, sociedade e cultura.
} 
Grossman e Helpman (1995), ainda restritos ao caso particular de um jogo bilateral, consideram a possibilidade de os grupos lobistas atuarem internacionalmente, pressionando ambos os governos a adotarem o formato do APC favorável aos seus interesses econômicos. Neste caso, o APC torna-se viável em três cenários diferentes, abaixo descritos:

$$
\begin{aligned}
& \text { (22) } a^{J}\left(W_{F}^{J}-W_{N}^{J}\right) \geq \max \left[0, \max \left(C_{i N}^{A}-C_{i F}^{A}\right), \max \left(C_{i N}^{B}-C_{i F}^{B}\right)\right] \text {, para } J=A, B \\
& \text { (23) } a^{A} W_{F}^{A}+a^{B} W_{F}^{B}+\sum_{i, J} C_{i F}^{J} \geq a^{A} W_{N}^{A}+a^{B} W_{N}^{B}+\sum_{i, J} C_{i N}^{J}+\sum_{i \in \Omega, J}\left(C_{i N}^{J}-C_{i F}^{J}\right) \\
& \text { (24) } a^{K} W_{F}^{K}+\sum_{i, J} C_{i F}^{J} \geq a^{K} W_{N}^{K}+\sum_{i, J} C_{i N}^{J} \text {, para } J, K=A, B \text { e } J \neq K
\end{aligned}
$$

As equações 22 a 24 representam, respectivamente, preferência unilateral não pressionada em favor do acordo preferencial de comércio nas duas economias, preferência unilateral pressionada favorável ao APC nas duas economias e, finalmente, preferência unilateral pressionada favorável ao APC na economia K e não-pressionada na economia J. Todos os resultados incluem a possibilidade de contribuições internacionais por parte dos grupos lobistas.

Mais uma vez, considerando-se apenas os resultados propostos nas equações 22 e 24 como exemplo, pode-se avaliar a aplicabilidade das conclusões de Grossman e Helpman (1995) para um processo de barganha internacional envolvendo $\mathrm{n}$ economias. Para tanto, suponha a necessidade de uma preferência unilateral pressionada favorável ao acordo em $\mathrm{h}$ economias, já existindo preferência unilateral não pressionada favorável ao acordo em (n-h) economias. As equações 25 e 26 descrevem, respectivamente, a condição necessária para a existência de uma preferência unilateral não pressionada favorável ao acordo preferencial de comércio em (n-h) economias e a condição necessária para a existência de uma preferência unilateral pressionada favorável ao acordo preferencial de comércio em h economias:

(25) $a^{J}\left(W_{F}^{J}-W_{N}^{J}\right) \geq \max \left[0, \max \left(C_{i N}^{J}-C_{i F}^{J}\right), \ldots, \max \left(C_{i N}^{n-h-J}-C_{i F}^{n-h-J}\right)\right]$, para $J \in(n-h)$ 
(26) $\sum_{k} a^{K} W_{F}^{K}+\sum_{i, J} C_{i F}^{J} \geq \sum_{k} a^{K} W_{N}^{K}+\sum_{i, J} C_{i N}^{J}$, para $J \in(n-h) e k \in h$

Ambas são extremamente restritivas quanto à viabilidade política do APC. A equação 25 praticamente descarta a possibilidade de existência de uma posição unilateral não pressionada, uma vez que a soma bem-estar do eleitor médio em cada economia deveria superar todas as contribuições financeiras dos grupos lobistas em (n-h) economias. A equação 26, por outro lado, exigiria uma ação política coordenada de todos os grupos lobistas das (n-h) economias com contribuições financeiras em todas as $\mathrm{h}$ economias em um montante suficiente para compensar os h governos da eventual perda de bem-estar do eleitor médio e de todas as contribuições lobistas favoráveis ao status quo.

Diante da limitação do jogo de barganha de Nash ao processo político envolvendo $\mathrm{n}$ economias tão distintas com igual poder de veto na formatação de um APC, propõe-se uma nova aplicação do jogo não-cooperativo de Stackelberg também para n economias, ampliando os resultados demonstrados no capítulo 4 desta tese.

\subsection{O jogo político não-cooperativo de Stackelberg com n jogadores}

No capítulo 4 desta tese, a substituição do jogo de barganha de Nash entre duas economias por um jogo não-cooperativo de Stackelberg entre uma grande economia e uma pequena economia originou as proposições 1 e 2 :

Proposição 1: Existe um equilíbrio coalition-proof para a pequena economia em um jogo não-cooperativo de Stackelberg favorável ao APC se, e somente se:

(13) $\int_{i}\left[\left(1-\alpha_{i}\right)\left(a^{J} W_{i F}^{J}+C_{i I}^{J}\right)+\alpha_{i}\left(a^{J} W_{i N}^{J}+C_{i \Omega}^{J}\right)\right] d i-\int_{i}\left(a^{J} W_{i N}^{J}+C_{i N}^{J}\right) d i=0$ para $J=B$, com a exclusão dos setores $i \in\left[0, i^{* *}\right]$, onde $i^{* *} \geq 0$. 
Proposição 2: Existe um equilíbrio coalition-proof para a grande economia em um jogo não-cooperativo de Stackelberg favorável ao APC se, e somente se, o ganho de líder de Stackelberg for superior ao ganho Cournot-Nash.

No caso de um jogo não-cooperativo com n-1 pequenas economias versus uma grande economia, a liderança de Stackelberg continua relacionada à assimetria relativa entre seu tamanho desproporcionalmente maior e a sua participação relativa nos fluxos comerciais das pequenas economias. A simples aplicação das proposições 1 e 2 para todas as negociações bilaterais entre as pequenas economias e a grande economia origina as proposições 7 a 9 , conforme descrito abaixo:

Proposição 7: Existe um equilíbrio coalition-proof para cada pequena economia em um jogo não-cooperativo de Stackelberg favorável ao APC se, e somente se:

(27) $\int_{i}\left[\left(1-\alpha_{i}\right)\left(a^{-} W_{i \bar{F}}^{J}+C_{i I}^{J}\right)+\alpha_{i}\left(a^{-} W_{i N}^{\frac{J}{N}}+C_{i \Omega}^{J}\right)\right] d i-\int_{i}\left(a^{\underline{J}} W_{i N}^{\underline{J}}+C_{i N}^{J}\right) d i=0$ para $\underline{J}=1, \ldots, n-1$ com a exclusão dos setores $i \in\left[0, i^{\star \pm}\right]$, onde $i^{* \underline{J}} \geq 0$.

Proposição 8: Existe um equilíbrio coalition-proof para a grande economia em um jogo não-cooperativo de Stackelberg favorável ao APC se, e somente se, o ganho de líder de Stackelberg for superior ao ganho Cournot-Nash.

As proposições 7 e 8 apenas generalizam os resultados já apresentados nas proposições 1 e 2 para o caso particular de um jogo não-cooperativo bilateral. Já a proposição 9 reflete a real dificuldade de uma ALCA politicamente viável:

Proposição 9: Existe um equilíbrio coalition-proof em um jogo não-cooperativo de Stackelberg favorável ao APC se, e somente se, o conjunto de setores $i \in\left[0, i^{*}\right]$ for idêntico em todas as Sn negociações bilaterais existentes entre $n$ economias. ${ }^{29}$

\footnotetext{
${ }^{29}$ Onde $S n$ equivale à soma de uma progressão aritmética com razão -1 e $n$ termos, sendo (n-1) o primeiro termo e [n-(n-1)] o último termo da progressão aritmética.
} 
Com exceção de uma mera coincidência nas $S n$ negociações capaz de satisfazer a proposição 9 , pode-se esperar uma forte dificuldade em se obter um equilíbrio coalition-proof favorável ao acordo preferencial de comércio com (n-1) pequenas economias e uma grande economia. ${ }^{30}$

Eventualmente, a viabilidade política de um APC estaria relacionada à possibilidade de transferências compensatórias entre governos. Tal possibilidade, embora permitida no âmbito das negociações internacionais para a criação de APCs, ainda é pouco utilizada pelos paísesmembros de acordos de livre comércio. [Grossman e Helpman (1994,1995)]

Diante da possibilidade de transferências compensatórias entre governos em um jogo nãocooperativo de Stackelberg envolvendo (n-1) pequenas economias e uma grande economia, as economias mais beneficiadas com o formato do APC (incluindo a grande economia líder de Stackelberg) poderiam efetuar transferências compensatórias às mais prejudicadas pela definição do conjunto de setores econômicos excluídos do acordo.

Neste caso, as transferências compensatórias restringem-se apenas aos governos das economias envolvidas no processo de negociação, não incluindo, por simplificação, as contribuições financeiras de grupos lobistas para governos estrangeiros.

O equilíbrio coalition-proof para a grande economia neste primeiro estágio é dado pela equação 28 , onde $\Omega_{\bar{J}}$ refere-se ao conjunto médio de setores econômicos excluídos na negociação entre cada pequena economia e a grande economia líder de Stackelberg:

(28) $\int_{i \in \Omega_{\bar{J}}(T)}\left(\Pi_{i N}+a W_{i N}\right) d i+\int_{i \notin \Omega_{\bar{J}}(T)}\left(\Pi_{i F}+a W_{i F}\right) d i \geq \int_{i}\left(\Pi_{i N}+a W_{i N}\right) d i$

${ }^{30}$ Desde a Cúpula das Américas, realizada em dezembro de 1994 em Miami (Estados Unidos), já são 11 anos de negociações, encontros e minutas de acordo, sem uma definição para o formato e data de início da ALCA. 
Neste caso, assume-se que a grande líder de Stackelberg define $\Omega_{\bar{J}}$ com o objetivo de maximizar seu bem-estar político a partir dos diversos conjuntos $\Omega_{J}$ oriundos das negociações com as pequenas economias. Além disso, por simplificação matemática, assumese que a grande economia não estará envolvida em quaisquer transferências compensatórias.

Cada pequena economia $\mathrm{K}$ tem seu equilíbrio coalition-proof definido pela equação 29 :

(29) $\int_{i \in \Omega_{\bar{J}}(T)}\left(\Pi_{i N}^{K}+a W_{i N}^{K}\right) d i+\int_{i \notin \Omega_{\bar{J}}(T)}\left(\Pi_{i F}^{K}+a W_{i F}^{K}\right) d i+\int_{i} \int_{J} \omega^{K}(i, J) d J d i \geq \int_{i}\left(\Pi_{i N}^{K}+a W_{i N}^{K}\right) d i$, para $\mathrm{J} \neq \mathrm{K}$

onde $\iint_{i} \omega_{J}^{K}(i, J) d J d i$ representa o total de pagamentos líquidos recebidos pela pequena economia $K$ como resultado das transferências compensatórias pagas pelas $J$ demais pequenas economias, já descontadas as transferências compensatórias pagas pela própria pequena economia $K$.

Assim, no processo de negociações inerentes ao jogo não-cooperativo entre a grande economia líder de Stackelberg e as (n-1) pequenas economias seguidoras de Stackelberg, o equilíbrio coalition-proof favorável ao APC pode ser descrito pelas proposições 10 e 11:

Proposição 10: Existe um equilibrio coalition-proof para cada pequena economia em um jogo não-cooperativo de Stackelberg favorável ao APC se, e somente se:

$\int_{i}^{1}\left[\left(1-\alpha_{i}\right)\left(a^{-} W_{i \bar{F}}^{J}+C_{i I}^{J}\right)+\alpha_{i}\left(a^{-} W_{i \bar{N}}^{J}+C_{i \bar{\Omega}}^{J}\right)\right] d i-\int_{i}\left(a^{-}-W_{i \bar{N}}^{J}+C_{i N}^{J}\right) d i+\int_{i} \int_{J} \omega^{K}(i, J) d J d i=0$ para $\underline{J}=1, \ldots, n-1 ; \underline{J} \neq K$, com a exclusão dos setores $i \in\left[0, i^{\mu}\right]$, onde $i^{\mu} \geq 0$.

Proposição 11: Existe um equilibrio coalition-proof para a grande economia em um jogo não-cooperativo de Stackelberg favorável ao APC se, e somente se, o ganho de líder de Stackelberg for superior ao ganho Cournot-Nash.

Assim, pode-se concluir que a viabilidade política de um APC aumenta substancialmente com a possibilidade de transferências compensatórias entre as economias. Neste novo contexto, as 
economias com maior poder de negociação poderiam definir o formato do acordo que maximizasse seu bem-estar político e, então, desembolsariam transferências compensatórias às economias com menor poder de negociação como incentivo econômico à adesão ao APC.

Naturalmente, tal esquema de transferências unilaterais também seria possível no jogo de barganha de Nash proposto em Grossman e Helpman (1995) para negociações bilaterais, e generalizado neste trabalho para $n$ jogadores. No entanto, pode-se esperar que a grande economia obteria bem-estar inferior comparativamente ao jogo não-cooperativo, no qual sua posição estratégica como líder de Stackelberg maximizaria seu bem-estar.

Portanto, do ponto de vista da pequena economia, mesmo em um jogo político nãocooperativo envolvendo n-1 pequenas economias e apenas uma grande economia, a adesão a um APC politicamente viável é um jogo de soma zero, caso todas as economias tenham poder de veto e acesso completo a informações sobre as estratégias de seus oponentes. A existência de transferências compensatórias entre as pequenas economias apenas reforça esse resultado, em que as pequenas economias eventualmente beneficiadas pelo conjunto médio de setores excluídos definido pela grande economia em suas (n-1) negociações efetuam pagamentos compensatórios às demais pequenas economias prejudicadas pelo formato desse mesmo conjunto, que, na ausência deste mecanismo de transferência, inviabilizariam o APC.

Este resultado do modelo reforça as conclusões obtidas por Krishna (1998) e Krueger (1995) sobre a economia política dos acordos preferenciais de comércio, cujo modelo assume que o governo "vende" a estrutura de barreiras protecionistas àqueles grupos de interesse com contribuições financeiras mais elevadas, enquanto a atribuição de certa importância ao bemestar do agente-eleitor médio reflete simplesmente sua preocupação com os resultados políticos das próximas eleições. A política comercial torna-se um bem público, cujos benefícios são "capturados" por grupos de interesse politicamente organizados em detrimento dos interesses difusos e desorganizados do restante da população, resultando em um apoio político maior nos países-membros para acordos preferenciais de comércio com efeito desvio de comércio predominante.

Vale lembrar que o efeito desvio de comércio é diretamente proporcional ao volume dos fluxos de comércio internacional dos países-membros do APC com o resto do mundo. No 
entanto, a grande maioria dos países da América do Sul e da América Central e Caribe concentram seu comércio internacional com países do próprio continente americano, minimizando o efeito desvio de comércio.

Argumenta-se nesta tese que a dificuldade intrínseca ao processo de negociação para criação da ALCA está relacionada tanto à baixa viabilidade política de um APC envolvendo n países com igual poder de veto sobre o formato do acordo, como ao reduzido ganho oriundo do efeito desvio de comércio em países com fluxos comerciais concentrados com parceiros inclusos no acordo.

No atual contexto, como destacado em Pereira (2005), os Estados Unidos iniciaram uma seqüência de pequenos acordos de livre comércio com economias da América Central e América do Sul, em detrimento do foco nas negociações para a ALCA. O recente acordo com o Mercado Comum Centro Americano (Costa Rica, El Salvador, Guatemala, Honduras e Nicarágua), denominado Área de Livre Comércio Centro-Americano (CAFTA), simboliza a busca da grande economia por pequenos APCs com pequenas economias ou pequenas coalizões de pequenas economias, exercendo sua liderança de Stackelberg na definição do formato do acordo, em vez do desgaste político inerente a um processo de negociação entre 34 países com características, interesses e expectativas diferentes para a ALCA. 


\section{CONCLUSÃO}

Diante da relevância da negociação da Área de Livre Comércio das Américas para a economia brasileira e da relativa ausência de estudos teóricos e empíricos a respeito dos impactos potenciais do acordo sobre o Brasil, o objetivo desta tese de doutorado foi analisar a economia política da ALCA a partir da interação entre grupos de interesse politicamente organizados e os respectivos governos nacionais interessados tanto nas contribuições financeiras decorrentes do alinhamento da política de comércio exterior às demandas dos grupos de interesse como no bem-estar de um agente-eleitor médio.

A análise de economia política apresentada substitui a tradicional solução de barganha de Nash por um jogo político seqüencial não-cooperativo de Stackelberg, onde a pequena economia pode escolher entre o status quo e o APC, enquanto a grande economia líder de Stackelberg obtém resultados mais favoráveis em comparação ao equilíbrio de barganha de Nash. Neste modelo, os governos não podem ser considerados simplesmente como uma entidade benevolente maximizadora exclusiva do bem-estar social e dos interesses nacionais, mas como um agente maximizador de seus próprios interesses financeiros e eleitorais.

Vale dizer, o primeiro estágio do jogo bilateral desenvolvido nesta tese é idêntico ao primeiro estágio do jogo político seqüencial entre duas economias simétricas proposto por Grossman e Helpman (1995). Esta tese pretende contribuir com a modificação do segundo estágio do jogo original, incorporando explicitamente no modelo a assimetria entre os jogadores. Neste novo contexto, a solução de barganha de Nash torna-se uma estratégia dominada, uma vez que a grande economia tem a oportunidade de aumentar seu ganho em detrimento da pequena economia em um jogo não-cooperativo de Stackelberg.

Em seguida, mantendo-se a estrutura não-cooperativa e seqüencial do jogo, analisa-se o poder de negociação da pequena economia na definição do formato do acordo preferencial de comércio em duas situações particulares, a saber: existência de oportunidades externas e a formação de uma coalizão com outras pequenas economias. 
Finalmente, a estrutura bilateral é generalizada para um processo de negociação internacional envolvendo n economias, seja no jogo de barganha de Nash, seja no jogo não-cooperativo de Stackelberg. Analisam-se as hipóteses de contribuições internacionais por parte dos grupos lobistas nacionais e de transferências compensatórias entre governos como mecanismo de aumentar a viabilidade política de acordos preferenciais de comércio potencialmente danosos a pequenas economias com baixo poder de negociação.

Os principais resultados desta tese são: em um jogo não-cooperativo de Stackelberg, o equilíbrio coalition-proof para o formato do acordo de livre comércio torna a pequena economia indiferente entre o status quo e o acordo e proporciona à grande economia um ganho de bem-estar superior à solução de barganha de Nash; a possibilidade de uma estratégia conjunta entre pequenas economias para a formação de um acordo de livre comércio com uma grande economia proporciona às pequenas economias um bem-estar potencialmente superior ao equilíbrio de seguidora de Stackelberg; a existência de oportunidades externas à pequena economia aumenta seu poder de negociação e seu bem-estar comparativamente ao jogo nãocooperativo de Stackelberg; a generalização do jogo de barganha bilateral de Nash para n economias reduz sensivelmente a viabilidade política de um acordo preferencial de comércio, quando todas as economias têm igual poder de veto e todas as decisões devem ser em consenso; e, finalmente, a inclusão de transferências compensatórias entre governos aumenta a viabilidade política de um acordo preferencial de comércio em um jogo não-cooperativo, embora a grande economia obtenha um ganho inferior ao obtido na estrutura bilateral do mesmo jogo. 


\section{REFERÊNCIAS}

ABREU, M. P. O Brasil e a ALCA: interesses e alternativas. Rio de Janeiro: PUC-RJ, 1995 (texto para discussão 371).

ADMATI, A. R.; PERRY, M. Strategic delay in bargaining. Review of Economic Studies, 54: 345-64, 1987.

ALCA. Minuta de acordo. Capítulo II — Disposições Gerais, FTAA.TNC/w/133/Rev.3, 2004.

BALBOA, O. I. et al. Market structure and the demand for free trade. Vanderbilt University, working paper, 2001.

BALDWIN, R. E. The political economy of postwar U.S. trade policy. The Bulletin, New York: New York University, 1976.

BERNHEIM, B. D. et al. Coalition-Proof Nash Equilibria I: Concepts, Journal of Economic Theory, 42: 1-12, 1987.

; WHINSTON, M. D. Menu auctions, resource allocation and economic influence, Quarterly Journal of Economics, 101 (1): 1-31, 1986.

13-29, 1987.

Coalition-Proof Nash Equilibria II: Applications, Journal of Economic Theory, 42:

BHAGWATI, J. Trade-diverting customs unions and welfare-improvement: a clarification, Economic Journal, (September): 580-87, 1971.

. Lobbying and welfare, Journal of Public Economics, 14: 355-63, 1980.

; PANAGARIYA, A. The theory of preferential trade agreements: historical evolution and current trends, American Economic Review, 86: 82-87, 1996.

; SRINIVASAN, T. N. Revenue seeking: a generalisation of the theory of tariffs, Journal of Public Economics, 88(6): 1069-87, 1980.

BINMORE, K. et al. The Nash bargaining solution in economic modelling, Rand Journal of Economics, 17 (2): 176-188, 1986.

BRASIL. IPEA, Brazil, Mercosur and the free trade areas of the Americas. 2000. v. I e II. 
BRAZILIAN EMBASSY. U.S. barriers to Brazilian goods and services. Washington D.C., 2001.

BROCK, W. A.; MAGEE, S. P. The economics of special interest politics: the case of the tariff, American Economic Review Proceedings, 68: 246-50, 1978.

CARVALHO, A.; PARENTE, A. Impactos comerciais da área de livre comércio das Américas. IPEA, 1999 (texto para discussão 635).

CHO, I. K. Uncertainty and delay in bargaining, Review of Economic Studies, 57: 575-95, 1990.

COATES, D. E.; LUDEMA, R. D. A theory of trade policy leadership, Journal of Development Economics, 65, 1-29, 2001.

DEKEL, E. Simultaneous offers and the inefficiency of bargaining: a two-period example, Journal of Economic Theory, 50: 300-8, 1990.

DIXIT, A.; NORMAN, V. D. The theory of international trade. Cambridge: Cambridge University Press, 1980.

ETHIER, W. E. Regionalism in a multilateral world, Journal of Political Economy, 106(6):1214-1245, 1998.

EXAME, edições 736, 740 e 751, 2001.

FARRELL, J.; GIBBONS, R. Cheap talk can matter in bargaining, Journal of Economic Theory, 48: 221-37, 1989.

FRIEDMAN, J. W. A non-cooperative equilibrium for supergames, Review of Economic Studies, March, 1-12, 1970.

FTAA. Free Trade Area of Americas, draft texts, www.ftaa-alca.org, 2001.

FUDENBERG, D.; KREPS, D. M. Reputation in the simultaneous play of multiple Opponents, Review of Economic Studies, LIV, 541-68, 1987.

; LEVINE, D. Subgame-perfect equilibria of finite- and infinite-horizon games, Journal of Economic Theory, 31: 251-68, 1983.

; . Reputation and equilibrium selection in games with a patient player, Econometrica, 57 (4): 759-78, 1989. 
; TIROLE, J. Sequential bargaining with incomplete information, Review of Economic Studies, 50: 221-47, 1983.

; __ Game theory. The MIT Press, 2000.

et al. On the robustness of equilibrium refinements, Journal of Economic Theory, 44: 354-80, 1988.

et al. Incomplete information bargaining with outside opportunities, Quarterly Journal of Economics, pp. 37-50, 1987.

FUNCEX. Barreiras comerciais às exportações brasileiras 1999. SECEX.

Grossman, G. M.; HelPMAN, E. Protection for sale, American Economic Review, 84:833-850, 1994.

$\frac{}{667-690}, \frac{}{1995 .}$. The politics of free-trade agreements, American Economic Review, 85:

; Perry, M. Sequential bargaining under asymmetric information, Journal of Economic Theory, 39: 120-54, 1986.

HARSANYI, J. Games with incomplete information played by Bayesian players, Management Science, 14: 320-34, 1967.

; SELTEN, R. A generalized Nash solution for two person bargaining games with incomplete information, Management Science, 18: 80-106, 1972.

HELPMAN, E. Politics and trade policy. NBER, working paper 5309, 1995.

; KRUGMAN, P., Trade policy and market structure. The MIT Press, 1991a.

; __ market structure and foreign trade. The MIT Press, $1991 \mathrm{~b}$.

HILLMAN, A. L. Declining industries and political-support protectionist motives, American Economic Review, (72) 5: 1180-7, 1982.

; URSPRUNG, H. W. Domestic politics, foreign interests and international trade policy, American Economic Review, 78(4): 729-45, 1988.

KEMP, M. C.; WAN, H. An elementary proposition concerning the formation of customs unions, Journal of International Economics, 6: 95-97, 1976. 
KRISHNA, P. Regionalism and multilaterism: a political economy approach, Quarterly Journal of Economics, 113: 227-251, 1998.

KRUEGER, A. The political economy of rent-seeking society, American Economic Review, 64: 291-303, 1974.

. Free trade agreements versus customs unions. NBER, working paper 5084, 1995. 1999.

. Trade creation and trade diversion under NAFTA. NBER, working paper 7429,

. Is bilaterism bad?. In HELPMAN, E.; RAZIN, A. (Eds.). International trade and trade policy. Cambridge: MIT Press, 1991.

; OBSTFELD. International economics - theory and policy. 4th ed., 1997.

KUME, H.; PIANI, G. ALCA: Uma estimativa do impacto no comércio bilateral BrasilEstados Unidos. São Paulo: IPEA, 2005 (texto para Discussão n. 1058).

LEVY, P. I. A political-economy analysis of free trade agreements, American Economic Review, 87: 513-526, 1997.

LIPSEY, R. G. The theory of customs unions: trade diversion and welfare, Economica, February, 1957.

LUCINDA, C. R. A integração econômica do Cone Sul: um estudo sobre os condicionantes econômicos dos fluxos de comércio. São Paulo, 1999. Dissertação (Doutorado em Economia de Empresas). EAESP/FGV, 1999.

MAILATH, G. J.; POSTLEWAITE, A. Asymmetric information bargaining problems with many agents, Review of Economic Studies, 57: 351-67, 1990.

MAYER, W. Endogenous tariff formation, American Economic Review, 74 (5) : 970-85.

MICHAELY, M. Partners to a preferential trade agreement: implications of varying size, Journal of International Economics, 46: 73-85, 1998.

NASH, J. F. The bargaining problem, Econometrica, 18: 155-2, 1950. . Two-person cooperative games, Econometrica, 21: 128-40, 1953.

OBSTFELD, M. EMU: ready or not?, NBER, working paper 6682, 1998. 
; ROGOFF, J. K. Foundations of International Macroeconomics. Cambridge: MIT Press, 1998.

PEREIRA, L. V. Agenda de Integração Brasileira: uma avaliação preliminar, Revista de Conjuntura Econômica, especial, maio: pp.26-31, 1997.

. A CAFTA na agenda do Mercosul na ALCA, Revista de Conjuntura Econômica, v.59, n. 09, pp. 42-3, 2005.

RICHARDSON, M. Endogenous protection and trade diversion, Journal of International Economics, 34: 309-24, 1993.

ROSENTHAL, R. W. Sequences of games with varying opponents, Econometrica, 47 (6): 1353-66, 1979.

RUBINSTEIN, A. Perfect equilibrium in a bargaining model, Econometrica, 50: 97-109, 1982.

SAMUELSON, P. The gains from international trade once again, Economic Journal, 72, 820-9, 1962.

SCHIFF, M. Small is beautiful: preferential trade agreements and the impact of country Size, market share, efficiency, and trade policy. World Bank, working paper 1668, 1996.

TIROLE, J.The theory of industrial organization. Cambridge: The MIT Press, 2000.

TREFLER, D. Trade liberalization and the theory of endogenous protection: an econometric study of U.S. import policy, Journal of Political Economy, 101(1): 138-60, 1993.

USCBP. What every member of the trade community should know about: tariff classification, U.S. Customs and Border Protection, May, 2004.

USTR. U.S. Positions in the Free Trade Area of Americas, www.ustr.gov, 2001.

VINER, J. The customs union issue. New York, 1950.

WORLD BANK. World Development Indicators, CD-Room, 2001. 


\section{Apêndice}

\section{A.1 ALCA: Antecedentes e estrutura negociadora}

A partir da "Iniciativa para as Américas", lançada em 1990 pelos EUA, as expectativas em torno da formação de um APC no continente americano levaram à realização, em 1994, da Primeira Cúpula das Américas em Miami (EUA), onde foi lançada a proposta para a criação da Área de Livre Comércio das Américas.

Entre 1995 e 1997 foram realizadas três Reuniões Ministeriais — respectivamente em Denver (EUA), Cartagena (Colômbia) e Belo Horizonte (Brasil) — nas quais foram organizados grupos de trabalho para o levantamento de informações relevantes às negociações para a criação da ALCA. Em 1998, na cidade de San José (Costa Rica), foi realizada a Quarta Reunião Ministerial para a definição dos princípios gerais da ALCA. Em 1999, na cidade de Santiago (Chile), foi realizada a Segunda Cúpula das Américas, para a definição da estrutura negociadora, cujas minutas referentes aos nove grupos de negociação foram preparadas na Sexta Reunião Ministerial realizada em Toronto (Canadá) no mesmo ano. A Sétima Reunião Ministerial, realizada em 2001 na cidade de Buenos Aires (Argentina), definiu os princípios negociadores da ALCA. Finalmente, a Terceira Cúpula das Américas realizada em Quebec (Canadá) apresentou o primeiro esboço dos capítulos do Acordo de Livre Comércio [ver FTAA (2001)], confirmando os princípios negociadores e os prazos.

A estrutura negociadora da ALCA estabelece que a cada 18 meses um país é designado para coordenar as negociações (em ordem cronológica: Canadá, Argentina, Equador e Brasil Estados Unidos). Paralelamente, o foro das negociações assume caráter rotativo entre as cidades de Miami (entre 1998 e 2001), Cidade do Panamá (entre 2001 e 2003) e Cidade do México (entre 2003 e 2004).

A atual estrutura negociadora é composta por um Comitê de Negociações Comerciais cuja responsabilidade é supervisionar as negociações, nove Grupos de Negociação, um Grupo Consultivo sobre Economias Menores, um Comitê de Representantes Governamentais sobre a Participação da Sociedade Civil, um Comitê sobre Comércio Eletrônico e, finalmente, um Comitê Tripartite formado por BID, OEA e CEPAL para assistência técnica. 
Vide Figuras 2 e 3.

Figura 2: Estrutura negociadora da área de livre comércio das Américas

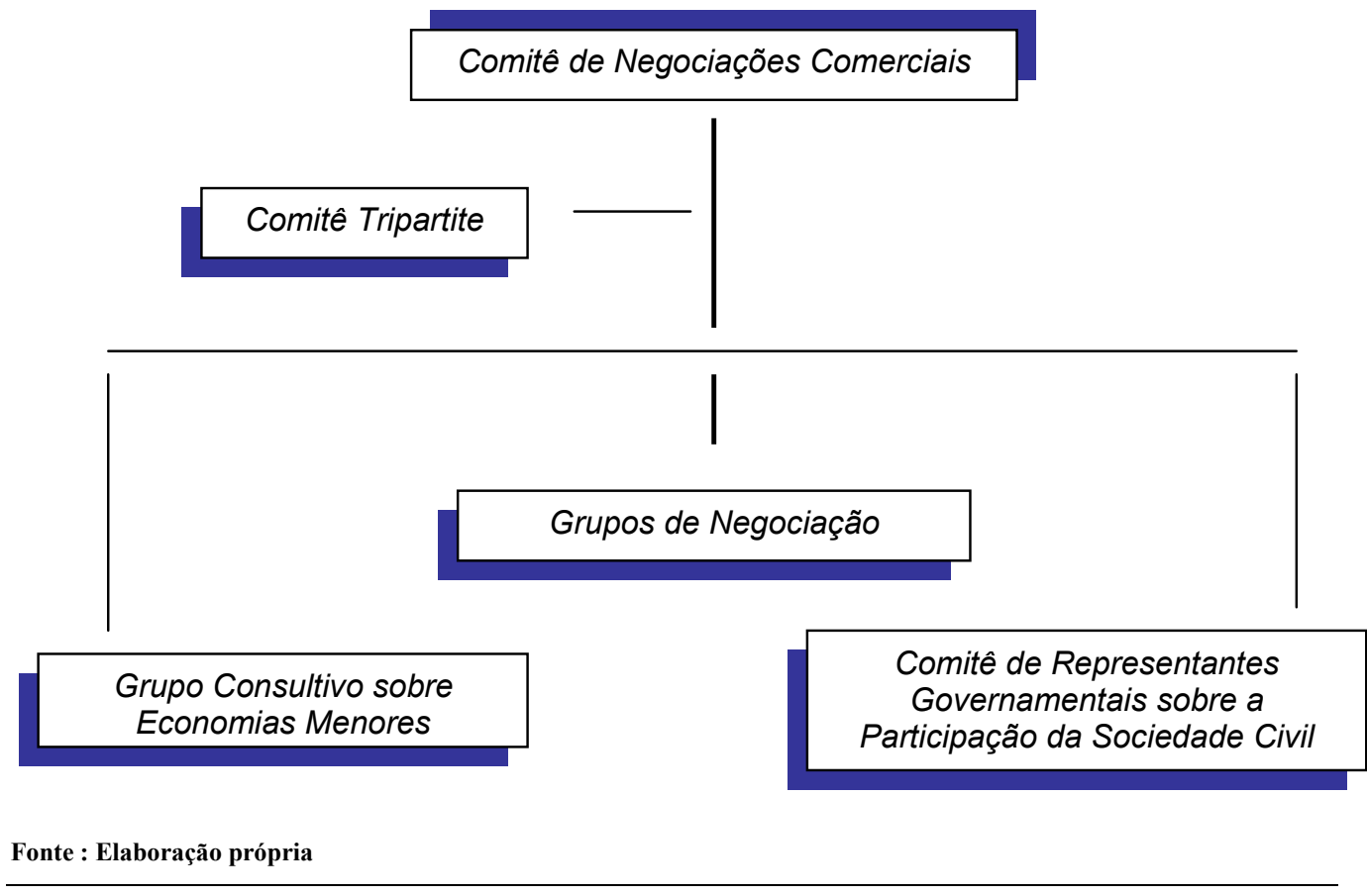

Figura 3: Grupos negociadores para a criação da área de livre comércio das Américas

Direitos Compensatórios e Antidumping

Direitos de Propriedade Intelectual

Investimentos

Agricultura

Á́REA de LIVRe Comércio das AmÉRICAS

Acesso a Mercados

Serviços

Solução de Controvérsias

Compras Governamentais

Solução de Controvérsias

Políticas de Competição

Fonte: Elaboração própria 
Como já destacado, a ALCA não se resume à simples criação de uma nova área de livre comércio mais ampla do que as já existentes no continente americano, onde apenas são eliminadas as barreiras comerciais entre os países-membros do bloco. Foram criados nove grupos de negociação (a saber, acesso a mercados, agricultura, compras governamentais, direitos de propriedade intelectual, serviços, investimentos, direitos compensatórios e antidumping, solução de controvérsias, política de competição) compostos por representantes dos 34 países.

O grupo de negociação de Acesso a Mercados abrange a eliminação de barreiras tarifárias e não-tarifárias no comércio intra-regional do hemisfério, implantação de procedimentos alfandegários eficientes e transparentes, defesa das regras de origem e aplicação de salvaguardas. A eliminação de barreiras tarifárias pode incluir prazos de ajustamento para setores econômicos mais sensíveis à competição externa, enquanto a eliminação de barreiras não-tarifárias requer tanto um minucioso levantamento como um constante monitoramento das práticas de cada país. A regra de origem define se o produto pode ser classificado como produzido no país membro do acordo preferencial de comércio, evitando a "triangulação" de produtos. Finalmente, em função de eventuais surtos de importações inesperados que prejudiquem as indústrias domésticas, justifica-se a aplicação de salvaguardas.

O grupo de negociação Agricultura foi criado em função da importância do setor agrícola para a maioria dos países do hemisfério e em virtude da utilização de subsídios e medidas fitossanitárias por parte dos países desenvolvidos. Argumenta-se que as regras da OMC para o setor agrícola são insuficientes.

O grupo de negociação Direitos Compensatórios e Antidumping tem como objetivo evitar a utilização de medidas antidumping como um mecanismo de proteção sob o argumento "disfarçado" de punição de práticas desleais ao comércio. Vale dizer, os Estados Unidos têm utilizado continuamente direitos compensatórios e antidumping contra seus parceiros comerciais.

O grupo de negociação Compras Governamentais tenta assegurar a inexistência de práticas discriminatórias entre produtores nacionais e internacionais para as compras governamentais. 
No entanto, não existe a tentativa de tornar idênticos todos os processos de licitações dos diversos governos.

O grupo de negociação Direitos de Propriedade Intelectual foi criado em função do descontentamento dos Estados Unidos com as regras estabelecidas pela Rodada Uruguai do GATT, sendo que o debate será marcado pelos conflito entre as regras da OMC e do NAFTA.

O grupo de negociação Investimentos, a princípio, manterá as mesmas regras criadas pela $\mathrm{OMC}$, abrangendo temas como políticas domésticas para investimentos diretos estrangeiros, disposição para o livre trânsito de executivos das empresas multinacionais, metas de exportações e transferência de tecnologia.

O grupos de negociação Serviços apresenta um compromisso para a liberalização dos serviços mais geral do que a prevista pela $\mathrm{OMC}$, mas com a possibilidade de os países apresentarem lista de exceções.

O grupo de negociação Solução de Controvérsias procura determinar quais procedimentos serão utilizados na presença de controvérsias entre os países-membros da ALCA.

Por último, o grupo de negociação Política de Competição refere-se à definição de regras que impeçam o abuso de poder econômico por parte das empresas multinacionais e adoção de políticas públicas discriminatórias entre empresas nacionais e multinacionais.

Finalmente, com relação aos princípios negociadores da ALCA propostos na Declaração de São José e confirmados na Terceira Cúpula das Américas, tem-se: compromisso de término das negociações até 2005; decisões acordadas devem ser por consenso em um compromisso único entre os 34 países (single undertaking); possibilidade de negociação individualmente ou em blocos regionais; conformidade com as regras da $\mathrm{OMC}$; e possibilidade de coexistência da ALCA com outros acordos preferenciais de comércio. 


\section{A.2 Modelo Grossman e Helpman (1995): definições e proposições}

Definição A.1: A escolha de um regime de comércio $R \in\{N$. F \} é uma preferência unilateral, se existe um conjunto de contribuições financeiras $\left\{C_{i F}, C_{i N\}}\right\}$ para cada grupo lobista $i$, tal que :

(i) $C_{i K} \geq 0$, para $K=N, F e \forall i$

(ii) $C_{i K} \leq \max \left(0, \pi_{i K}-\pi_{i J}\right)$, para $J=N, F$ e $J \neq K$

(iii) $\sum_{i} C_{i R}+a W_{R} \geq \sum_{i} C_{i K}+a W_{K}$

(iv) $\forall$ grupo lobista $i$, não existe $\hat{C}_{i N} \geq 0, \hat{C}_{i F} \geq 0$ e um regime $\hat{R}_{i} \in\{N, F\}$, tal que :

(a) $\hat{C}_{i \hat{R}_{i}}+\sum_{j \neq i} C_{j \hat{R}_{i}}+a W_{\hat{R}_{i}} \geq \hat{C}_{i K}+\sum_{j \neq i} C_{j K}+a W_{K}$

(b) $\pi_{i \hat{R}_{i}}-\hat{C}_{i \hat{R}_{i}}>\pi_{i R}-C_{i R}$

Definição A.2 : O conjunto de setores excluídos politicamente ótimo $\Omega(T)$ é o conjunto dos setores $i$, tal que $i \in\left[0, \min \left(i_{0}, \hat{i}\right)\right]$, onde $\hat{i}$ satisfaz $\int_{i=0}^{\hat{i}} T_{i} d i=T$.

Proposição A.1: Existe uma preferência unilateral não pressionada em favor do regime $R$ se, e somente se:

$a\left(W_{R}-W_{\widetilde{R}}\right) \geq \max \left[0, \max _{i}\left(\pi_{i \widetilde{R}}-\pi_{i R}\right)\right]$

Prova : De um lado, assumindo todas as contribuições financeiras lobistas iguais a zero, o governo escolhe o regime socialmente desejável e, naturalmente, $a\left(W_{R}-W_{\widetilde{R}}\right) \geq 0$. Por outro lado, se $a\left(W_{R}-W_{\widetilde{R}}\right)<\left(\pi_{i \widetilde{R}}-\pi_{i R}\right)$ para qualquer $i$, então o grupo lobista i consideraria lucrativo oferecer uma contribuição financeira entre $a\left(W_{R}-W_{\widetilde{R}}\right)$ e $\left(\pi_{\tilde{R}}-\pi_{i R}\right)$ induzindo o governo a optar pelo regime $\widetilde{R}$. 
Proposição A.2: Se existir uma preferência unilateral pressionada em favor do regime $R$, então:

$\sum_{i} \pi_{i R}+a W_{R} \geq \sum_{i} \pi_{i \widetilde{R}}+a W_{\widetilde{R}}$.

Prova : Seja $C_{i R}>0$ para pelo menos um grupo lobista $i$, então o governo encontrase indiferente entre os dois regimes de comércio. Caso contrário, os grupos lobistas em favor de $R$ poderiam reduzir suas contribuições sem afetar o resultado final, aumentando seu lucro líquido. Com o governo indiferente, os grupos lobistas em favor do regime $\widetilde{R}$ oferecem contribuições financeiras equivalentes às perdas esperadas sob o regime $R$, enquanto nenhum dos grupos lobistas em favor do regime $R$ oferecem contribuições financeiras superiores aos lucros esperados sob o regime R. Finalmente, os grupos lobistas oferecem contribuições financeiras nulas caso o regime comercial de sua preferência não seja escolhido pelo governo.

Proposição A.3: Sempre existe uma preferência coalition-proof. Tal preferência é favorável ao regime comercial $R$ se, e somente se, $\sum_{i} \pi_{i R}+a W_{R} \geq \sum_{i} \pi_{\tilde{R}}+a W_{\widetilde{R}}$ for satisfeita.

Prova: Suponha que haja uma preferência unilateral não pressionada pelo regime $R$ e uma preferência unilateral pressionada pelo regime $\widetilde{R}$. Além disso, suponha um mínimo de coordenação entre os grupos lobistas. Assim, como os indivíduos favoráveis ao regime $R$ não contribuem financeiramente, os produtores prejudicados pelo regime $R$ podem formar uma coalizão em prol do regime $\widetilde{R}$. Então, os grupos lobistas oferecem o montante de contribuições financeiras suficiente ao governo para reverter sua decisão e, como há uma preferência unilateral pressionada pelo regime $\widetilde{R}$, todos os membros do grupo lobista têm seu bem-estar elevado. Portanto, um regime de comércio será um equilíbrio coalitionproof caso seja satisfeita a restrição $\sum_{i} \pi_{i R}+a W_{R} \geq \sum_{i} \pi_{i \widetilde{R}}+a W_{\widetilde{R}}$. 
Proposição A.4: Existe um equilíbrio coalition-proof para o acordo de livre comércio se, e somente se :

$$
\int_{i \in \Omega(T)}\left(\Pi_{i N}+a W_{i N}\right) d i+\int_{i \notin \Omega(T)}\left(\Pi_{i F}+a W_{i F}\right) d i \geq \int_{i}\left(\Pi_{i N}+a W_{i N}\right) d i
$$

e existe uma preferência unilateral não pressionada com $R=F$ se, e somente se:

$\int_{i \in \Omega(T)}\left(a W_{i N}\right) d i+\int_{i \notin \Omega(T)}\left(a W_{i F}\right) d i+C \geq \int_{i}\left(a W_{i N}\right) d i$

onde $C=\int_{i \in \Omega(T)} \max \left[0, a\left(W_{i F}-W_{i N}\right)+\max _{j \notin \Omega(T)}\left(-T_{i} g_{i}\right)\right] d i$.

Prova: A proposição A.4 estabelece que tanto a preferência unilateral pressionada como a preferência unilateral não pressionada definem o mesmo conjunto de setores excluidos. Suponha, ao contrário, que exista uma preferência unilateral pressionada para a exclusão de parte dos setores $i \in \Omega(T)$ que, entretanto, não são excluídos do acordo em prol de outros setores $i \notin \Omega(T)$. De um lado, se não existirem tais setores $i$, então os setores $i$ estariam dispostos a oferecer contribuições financeiras até $\Pi_{i N}-\Pi_{i F} \geq 0$ que, conforme definição de $\Omega(T)$, são superiores aos custos politicos a $\left(W_{i F}-W_{i N}\right)$. De outro lado, se existirem tais setores $j$ na lista de exclusão, escolhe-se um subconjunto $\tilde{I}$ e $\widetilde{J}$ dos setores $i$ e $j$, respectivamente, tal que $\int_{i \in \widetilde{I}} T_{i} d i=\int_{j \in \widetilde{J}} T_{j} d j$. Assim, os setores $j \in \widetilde{J}$ ofereceriam no máximo $\int_{j \in \widetilde{J}}\left(\Pi_{j N}-\Pi_{j F}\right)$ dj para serem incluidos no conjunto $\Omega(T)$. Mais uma vez, a definição de $\Omega(T)$ estabelece que os grupos lobistas $i \in \widetilde{I}$ ofereceriam algo igual ou inferior aos ganhos vinculados à exclusão de tais setores do acordo do livre comércio e, finalmente, que tais contribuições financeiras seriam suficientes para induzir o governo a excluir os setores $i \in \widetilde{I}$ em vez dos setores $j \in \widetilde{J}$. 


\section{A.3 Jogo político bilateral não-cooperativo de Stackelberg: proposições e provas}

Proposição 1: Existe um equilíbrio coalition-proof para a pequena economia em um jogo não-cooperativo de Stackelberg favorável ao APC se, e somente se:

(13) $\int_{i}\left[\left(1-\alpha_{i}\right)\left(a^{J} W_{i F}^{J}+C_{i I}^{J}\right)+\alpha_{i}\left(a^{J} W_{i N}^{J}+C_{i \Omega}^{J}\right)\right] d i-\int_{i}\left(a^{J} W_{i N}^{J}+C_{i N}^{J}\right) d i=0$ para $J=B$, com a exclusão dos setores $i \in\left[0, i^{* *}\right]$, onde $i^{* *} \geq 0$.

Prova: De acordo com a proposição 1, no equilibrio de Stackelberg, a pequena economia ficará indiferente entre o status quo (segunda integral do lado esquerdo da equação 13) e o APC com exclusão dos setores $i \in\left[0, i^{* *}\right]$ (primeira integral do lado esquerdo da equação 13). Isso porque a pequena economia é uma seguidora de Stackelberg e, portanto, toma como dadas as decisões da grande economia. Assim, caso os ganhos com o APC superem os ganhos no status quo, há espaço para a grande economia aumentar a lista de seus setores excluídos do acordo. Por outro lado, caso os ganhos com o APC sejam inferiores aos ganhos no status quo, a pequena economia opta pelo segundo inviabilizando o APC. Portanto, somente quando a pequena economia está exatamente indiferente entre o status quo e o APC, tem-se o equilíbrio coalition-proof para o jogo não-cooperativo.

Proposição 2: Existe um equilíbrio coalition-proof para a grande economia em um jogo não-cooperativo de Stackelberg favorável ao APC se, e somente se, o ganho de líder de Stackelberg for superior ao ganho Cournot-Nash.

Prova: De acordo com a proposição 2, o bem-estar da grande economia associado ao APC com a exclusão dos setores $i \in\left[0, i^{* *}\right]$ é superior ao bem-estar da grande economia em um equilíbrio de barganha de Nash onde são excluídos os setores $i \in$ [0, $\left.i^{*}\right]$ desenvolvido por Grossman e Helpman (1995). Caso contrário, a grande economia poderia abdicar de sua condição de líder de Stackelberg e participar de um jogo de barganha. Ver Balboa et al. (2001). 
Proposição 3: (sem custos de adiamento) Dada a existência de oportunidades externas à pequena economia, existe um equilíbrio coalition-proof favorável ao APC com a grande economia se, e somente se:

(15) $\Psi \geq \max \left\{0,\left[\int_{i}\left[\left(1-\alpha_{i}\right)\left(a^{C B} W_{i F}^{C B}+C_{i I}^{C B}\right)+\alpha_{i}\left(a^{C B} W_{i N}^{C B}+C_{i \Omega}^{C B}\right)\right] d i-\int_{i}\left(a^{C B} W_{i N}^{C B}+C_{i N}^{C B}\right) d i\right]\right\}$

com a exclusão dos setores $i \in\left[0, i^{\delta}\right], i^{\delta} \geq 0$, onde: AB refere-se ao acordo de livre comércio entre a pequena economia e a grande economia, e CB ao acordo da pequena economia com o novo parceiro comercial.

Prova: A proposição 3 estabelece que o acordo de livre comércio AB proporciona um bem-estar à pequena economia fracamente superior ao bem-estar proporcionado pelo acordo de livre comércio $C B$ e estritamente superior ao bemestar proporcionado por (13). Caso contrário, supondo $\Psi<0$, a pequena economia prefere o status quo ou a oportunidade externa. Por outro lado, a pequena economia prefere a oportunidade externa, se

$$
\begin{aligned}
& \Psi<\int_{i}\left[\left(1-\alpha_{i}\right)\left(a^{C B} W_{i F}^{C B}+C_{i I}^{C B}\right)+\alpha_{i}\left(a^{C B} W_{i N}^{C B}+C_{i \Omega}^{C B}\right)\right] d i-\int_{i}\left(a^{C B} W_{i N}^{C B}+C_{i N}^{C B}\right) d i \text {. Por último, se } \\
& \int_{i}^{[}\left[\left(1-\alpha_{i}\right)\left(a^{C B} W_{i F}^{C B}+C_{i I}^{C B}\right)+\alpha_{i}\left(a^{C B} W_{i N}^{C B}+C_{i \Omega}^{C B}\right)\right] d i-\int_{i}\left(a^{C B} W_{i N}^{C B}+C_{i N}^{C B}\right) d i=0 \text {, então a } \\
& \text { pequena economia permanece indiferente entre o status quo e o APC, } \\
& \text { independentemente do oponente. }
\end{aligned}
$$

Proposição 4: (com custos de adiamento) Dada a existência de oportunidades externas à pequena economia, existe um equilibrio coalition-proof favorável ao APC com a grande economia se, e somente se:

$$
\int_{i}\left[\left(1-\alpha_{i}\right)\left(a^{A B} W_{i F}^{A B}+C_{i I}^{A B}\right)+\alpha_{i}\left(a^{A B} W_{i N}^{A B}+C_{i \Omega}^{A B}\right)\right] d i-\int_{i}\left(a^{A B} W_{i N}^{A B}+C_{i N}^{A B}\right) d i=\Psi e
$$

$$
\Psi \geq \max \left\{0,\left[\int_{i}\left[\left(1-\alpha_{i}\right)\left(a^{C B} W_{i F}^{C B}+C_{i I}^{C B}\right)+\alpha_{i}\left(a^{C B} W_{i N}^{C B}+C_{i \Omega}^{C B}\right)\right] d i-\int_{i}\left(a^{C B} W_{i N}^{C B}+C_{i N}^{C B}\right) d i\right]-D\right\}
$$

com a exclusão dos setores $i \in\left[0, i^{\theta}\right], i^{\theta} \geq 0$, onde: $D$ representa o custo de adiamento nas negociações para a formação de um acordo de livre comércio. 
Prova: A proposição 4 estabelece que o acordo de livre comércio AB proporciona um bem-estar à pequena economia fracamente superior ao bem-estar proporcionado pelo acordo de livre comércio $C B$ e estritamente superior ao bemestar proporcionado por (13), descontando-se os custos de adiamento nas negociações. Caso contrário, supondo $\Psi<0$, a pequena economia prefere o status quo ou o acordo de livre comércio com o oponente $C$, desde que o ganho de bemestar decorrente do novo acordo de livre comércio supere o custo de adiamento D. Por outro lado, mesmo na presença de custos de adiamento, a pequena economia prefere a oportunidade externa, se

$$
\begin{aligned}
& \Psi<\int_{i}\left[\left(1-\alpha_{i}\right)\left(a^{C B} W_{i F}^{C B}+C_{i I}^{C B}\right)+\alpha_{i}\left(a^{C B} W_{i N}^{C B}+C_{i \Omega}^{C B}\right)\right] d i-\int_{i}\left(a^{C B} W_{i N}^{C B}+C_{i N}^{C B}\right) d i-D . \quad \text { Por } \\
& \text { último, se } \quad \int_{i}^{[}\left[\left(1-\alpha_{i}\right)\left(a^{C B} W_{i F}^{C B}+C_{i I}^{C B}\right)+\alpha_{i}\left(a^{C B} W_{i N}^{C B}+C_{i \Omega}^{C B}\right)\right] d i-\int_{i}\left(a^{C B} W_{i N}^{C B}+C_{i N}^{C B}\right) d i=0,
\end{aligned}
$$

então a pequena economia nunca prefere a oportunidade externa.

Proposição 5: Seja uma grande economia envolvida em negociações isoladas com diversas pequenas economias $j=1, \ldots, N$ para a formação de diversos APCs. Então, caso não haja coalizão entre as pequenas economias, o APC que resolve o processo de barganha exclui todos os setores $i_{j} \in\left[0, i_{j}{ }^{*}\right]$, onde $i_{j}{ }^{j}{ }^{j}$ é definido através da ponderação entre as perdas e os ganhos obtidos pelos grupos lobistas da grande economia e das pequenas economias. Neste caso, a grande economia obtém o ganho de lider de Stackelberg em todas as negociações, enquanto cada pequena economia permanece exatamente indiferente entre o status quo e o APC.

Prova: Na ausência de coalizão entre as pequenas economias nas negociações com a grande economia, esta assume o papel de líder de Stackelberg em todas as negociações e vale a proposição 1.

Proposição 6: Seja uma grande economia envolvida em negociações isoladas com diversas pequenas economias $j=1, \ldots, N$ para a formação de diversos acordos preferenciais de comércio. Então, caso haja coalizão entre as pequenas economias que resulte em uma única posição unilateral para o primeiro estágio do jogo, o acordo preferencial de comércio que resolve o processo de barganha exclui todos os 
setores $i \in\left[0, i^{\tau}\right]$, onde $i^{\tau}$ é definido através da ponderação entre as perdas e os ganhos obtidos pelos grupos lobistas da grande economia e das pequenas economias. Neste caso, a grande economia obtém um ganho igual ou inferior ao ganho de líder de Stackelberg, enquanto os ganhos decorrentes da formação da coalizão superam os ganhos de seguidora de Stackelberg.

Prova: Caso os ganhos obtidos pelas pequenas economias decorrentes da negociação em coalizão com a grande economia sejam iguais ou inferiores aos ganhos isolados de seguidora de Stackelberg, não há formação de uma coalizão. Isso porque, caso os ganhos sejam iguais aos ganhos de seguidora de Stackelberg, as pequenas economias preferem negociar individualmente ao invés de entrarem em uma coalizão que pode resultar em um conflito de preferências unilaterais. ${ }^{31}$ Caso os ganhos sejam inferiores aos ganhos de seguidora de Stackelberg, naturalmente não se justifica a formação de uma coalizão.

${ }^{31}$ Ver Apêndice de Grossman e Helpman (1995). 


\section{A.4 Jogo político com n países: proposições e provas}

Proposição 7: Existe um equilíbrio coalition-proof para cada pequena economia em um jogo não-cooperativo de Stackelberg favorável ao APC se, e somente se:

$$
\int_{i}\left[\left(1-\alpha_{i}\right)\left(a^{\underline{J}} W_{i \bar{F}}^{\underline{J}}+C_{i I}^{\underline{J}}\right)+\alpha_{i}\left(a^{\underline{\underline{J}}} W_{i \bar{N}}^{\underline{J}}+C_{i \Omega}^{\underline{J}}\right)\right] d i-\int_{i}\left(a^{\underline{J}} W_{i N}^{\underline{J}}+C_{i N}^{J}\right) d i=0 \text { para } \underline{J}=1, \ldots, n-1
$$

com a exclusão dos setores $i \in\left[0, i^{*}\right]$, onde $i^{* J} \geq 0$.

Prova: De acordo com a proposição 7, no equilibrio de Stackelberg, cada pequena economia ficará indiferente entre o status quo (segunda integral do lado esquerdo da equação 27) e o APC com exclusão dos setores $i \in\left[0, i^{*}\right]$ (primeira integral do lado esquerdo da equação 27). Isso porque cada pequena economia é uma seguidora de Stackelberg e, portanto, toma como dadas as decisões da grande economia. Assim, caso os ganhos com o APC superem os ganhos no status quo, há espaço para a grande economia aumentar a lista de seus setores excluidos do acordo. Por outro lado, caso os ganhos com o acordo de livre comércio sejam inferiores aos ganhos no status quo em pelo menos uma pequena economia, esta opta pelo segundo inviabilizando o APC, uma vez que todas as decisões devem ser por consenso entre todas as economias. Portanto, somente quando cada pequena economia está exatamente indiferente entre o status quo e o APC, tem-se o equilibrio coalition-proof para o jogo não-cooperativo para n economias.

Proposição 8: Existe um equilíbrio coalition-proof para a grande economia em um jogo não-cooperativo de Stackelberg favorável ao APC se, e somente se, o ganho de líder de Stackelberg for superior ao ganho Cournot-Nash.

Prova: De acordo com a proposição 8, o bem-estar da grande economia associado ao APC com a exclusão dos setores $i \in\left[0, i^{*-}\right]$ é superior ao bem-estar da grande economia em um equilíbrio de barganha de Nash onde são excluidos os setores $i \in$ $\left[0, i^{*}\right]$ desenvolvidos por Grossman e Helpman (1995). Caso contrário, a grande 
economia poderia abdicar de sua condição de líder de Stackelberg e participar de um jogo de barganha.

Proposição 9: Existe um equilíbrio coalition-proof em um jogo não-cooperativo de Stackelberg favorável ao APC se, e somente se, o conjunto de setores $i \in\left[0, i^{*-J}\right]$ for idêntico em todas as Sn negociações bilaterais existentes entre $n$ economias.

Prova: $O$ conjunto $i \in\left[0, i^{*}\right]$ deve ser um equilibrio coalition-proof no jogo nãocooperativo entre cada pequena economia e a grande economia líder de Stackelberg, também deve ser um equilíbrio coalition-proof no processo de negociação entre cada pequena economia com as demais pequenas economias participantes do referido APC, seja tal processo de negociação governado pela jogo de barganha de Nash descrito nas equações 20 e 21, seja também um jogo nãocooperativo entre pequenas economias. Caso contrário, como a Área de Livre Comércio das Américas tem como princípios básicos a adoção de decisões por consenso e a igualdade soberana das economias, basta a inviabilidade de um equilíbrio coalition-proof em uma pequena economia para comprometer toda viabilidade política do APC.

Proposição 10: Existe um equilíbrio coalition-proof para cada pequena economia em um jogo não-cooperativo de Stackelberg favorável ao APC se, e somente se:

$$
\int_{i}^{0}\left[\left(1-\alpha_{i}\right)\left(a^{-} W_{i \bar{F}}^{J}+C_{i \bar{I}}^{J}\right)+\alpha_{i}\left(a^{-} W_{i \bar{N}}^{J}+C_{i \bar{\Omega}}^{J}\right)\right] d i-\int_{i}\left(a^{-} W_{i \bar{N}}^{J}+C_{i N}^{J}\right) d i+\int_{i} \int_{J} \omega^{K}(i, J) d J d i=0
$$
para $\underline{J}=1, \ldots, n-1 ; \underline{J} \neq K$, com a exclusão dos setores $i \in\left[0, i^{\mu}\right]$, onde $i^{\mu} \geq 0$.

Prova: De acordo com a proposição 11, no equilíbrio de Stackelberg, cada pequena economia ficará indiferente entre o status quo e o APC com exclusão dos setores $i \in$ $\left[0, i^{\mu}\right]$, descontando-se os pagamentos líquidos de transferências compensatórias entre pequenas economias. Isso porque cada pequena economia é uma seguidora de Stackelberg e, portanto, toma como dadas as decisões da grande economia. Assim, 
caso os ganhos com o APC superem os ganhos no status quo com o conjunto $\bar{\Omega}$, esses ganhos serão utilizados no pagamento de transferências compensatórias aos governos com perda de bem-estar político. Por outro lado, caso os ganhos com o APC sejam inferiores aos ganhos no status quo, esta economia receberá transferências compensatórias das economias com ganhos de bem-estar proporcionados pelo conjunto $\bar{\Omega}$. Portanto, somente quando cada pequena economia estiver exatamente indiferente entre o status quo e o APC, incluindo o pagamento líquido de transferências compensatórias, tem-se o equilíbrio coalitionproof para o jogo não-cooperativo para n-1 pequenas economias.

Proposição 11: Existe um equilíbrio coalition-proof para a grande economia em um jogo não-cooperativo de Stackelberg favorável ao APC se, e somente se, o ganho de líder de Stackelberg for superior ao ganho Cournot-Nash.

Prova: De acordo com a proposição 12, o bem-estar da grande economia associado ao APC com a exclusão dos setores $i \in\left[0, i^{\mu}\right]$ é superior ao bem-estar da grande economia em um equilíbrio de barganha de Nash. Caso contrário, a grande economia poderia abdicar de sua condição de líder de Stackelberg e participar de um jogo de barganha. Alternativamente, em um caso intermediário, a grande economia poderia optar por negociar bilateralmente com cada pequena economia, caso os ganhos de bem-estar proporcionados pelo conjunto $i_{j} \in\left[0, i_{j}{ }^{* j}\right]$ definido na proposição 5 superassem o bem-estar relacionado ao equilibrio de barganha de Nash. 